IZA DP No. 8067

Female Brain Drains and Women's Rights Gaps:

A Gravity Model Analysis of Bilateral Migration Flows

Maryam Naghsh Nejad

Andrew T. Young

March 2014 


\title{
Female Brain Drains and Women's Rights Gaps: A Gravity Model Analysis of Bilateral Migration Flows
}

\author{
Maryam Naghsh Nejad \\ $I Z A$ \\ Andrew T. Young \\ West Virginia University \\ Discussion Paper No. 8067 \\ March 2014 \\ IZA \\ P.O. Box 7240 \\ 53072 Bonn \\ Germany \\ Phone: +49-228-3894-0 \\ Fax: +49-228-3894-180 \\ E-mail: iza@iza.org
}

\begin{abstract}
Any opinions expressed here are those of the author(s) and not those of IZA. Research published in this series may include views on policy, but the institute itself takes no institutional policy positions. The IZA research network is committed to the IZA Guiding Principles of Research Integrity.

The Institute for the Study of Labor (IZA) in Bonn is a local and virtual international research center and a place of communication between science, politics and business. IZA is an independent nonprofit organization supported by Deutsche Post Foundation. The center is associated with the University of Bonn and offers a stimulating research environment through its international network, workshops and conferences, data service, project support, research visits and doctoral program. IZA engages in (i) original and internationally competitive research in all fields of labor economics, (ii) development of policy concepts, and (iii) dissemination of research results and concepts to the interested public.
\end{abstract}

IZA Discussion Papers often represent preliminary work and are circulated to encourage discussion. Citation of such a paper should account for its provisional character. A revised version may be available directly from the author. 


\section{ABSTRACT \\ Female Brain Drains and Women's Rights Gaps: A Gravity Model Analysis of Bilateral Migration Flows}

In this paper we model the migration decisions of high-skilled women as a function of the benefits associated with moving from an origin with relatively low women's rights to a destination with a relatively high level of women's rights. However, the costs faced by women are decreasing in the level of women's rights provided. The model predicts a non-linear relationship between the relative levels of women's rights in destination versus origin countries (the women's rights gap) and the gender gap in high-skilled migration flows (the female brain drain ratio). In particular, starting from large values of the women's rights gap (where women's rights are very low in the origin) decreases in the gap may be associated with increases in the female brain drain ratio. However, starting from lower levels of the gap the relationship is positive: a greater gain in women's rights moving from origin to destination is, all else equal, associated with a greater likelihood of migration. Using a cross section of over 3,000 bilateral migration flows across OECD and non-OECD countries and the women's rights indices from the CIRI Human Rights Dataset, we report evidence consistent with the theory. A statistically significant and nonlinear relationship exists between women's rights gaps and female brain drain ratios. The evidence is particularly strong for the case of women's political rights.

JEL Classification: F22, J11, J61, J16, O17, O43

Keywords: female brain drain, high skilled female migration, bilateral migration flows, women's rights, institutional quality, gravity models

Corresponding author:

Maryam Naghsh Nejad

IZA

P.O. Box 7240

53072 Bonn

Germany

E-mail: Naghshnejad@iza.org 


\section{Introduction}

Female migration rates are higher than those of males in $88 \%$ of non-OECD countries. This relative tendency of females to migrate is most pronounced for high-skilled individuals. The migration rates of females with post-secondary education are on average $17 \%$ higher than those of males (Docquier, Lowell, and Marfouk, 2009). Furthermore, the migration rate of the highskilled - brain drain - is relatively greater for females on each of the inhabited continents. ${ }^{1}$ (See

\section{figure 1).}

Why are rates of female brain drain relatively high in developing countries? An outflow of human capital from developing countries is generally troubling. However, losses of female human capital are likely to be particularly costly. Researchers have reported that increased educational attainment by females is associated with them having lower fertility rates and improved health; their infant mortality rates tend to be lower and their children's educational attainment tends to be higher (Schultz (1988), Behrman and Deolalikar (1988), and Subbarao and Raney (1995)). According to Abu-Ghaida and Klasen (2004), the lost "social gains" from gender inequalities in education may amount to between 0.1 and 0.3 points in annual per capita income growth. $^{2}$

In this paper we explore one potential determinant of the rates of female brain drain relative to those of males: women's rights. In many developing countries, not only do women suffer from a lack of political rights and protections from violence. They also lack basic economic rights to productive resources:

Few farming women in developing countries have title and control of land in

\footnotetext{
${ }^{1}$ The data on continents here comes from Mayer and Zignago (2006). Asia, Africa, America, Europe and Pacific are the five possible continents associated with each country. Pacific refers to Australia and Pacific island countries. ${ }^{2}$ Knowles, Lorgelly, and Owen (2002) estimate a neoclassical growth model that explicitly includes both female and male human capital. Using cross-country data they find that increases in female education positively affect labor productivity while the effect of male education is often statistically insignificant or even negative.
} 
their own names. In many areas of sub-Saharan Africa, widows lack even basic rights to inherit marital property [.] In south Asia, women have gained greater legal inheritance rights over time, but inequitable restrictions continue to keep women at a disadvantage, and women's property rights in practice are much less than in the legal code[.] Women may also have less access [to] productive assets such as labor-saving technologies, credit, and extension services (Mammen and Paxson, 2000, p. 161).

Increases in women's rights can decrease both the costs and benefits to migration. Women's rights may, therefore, have a non-linear relationship to the rate of female brain drain in a country. For example, greater protection from physical coercion decreases the riskiness of trying to migrate but, at the same time, it creates an environment that an individual has less reason to flee.

We study over 3,000 observations of bilateral high-skilled migration rates and employ the women's rights index values from the Cingranelli and Richards (2010) (CIRI) Human Rights Dataset in the origin countries. Within a gravity model framework, female-to-male brain drain ratios are related to the ratio of the women's rights measures in the origin and destination countries (the women's rights gap). We estimate a statistically significant non-linear relationship between the women's rights gap and the migration rate of high-skilled females relative to that of high-skilled males from origin to destination countries (the female brain drain ratio). In particular, starting from large values of the women's rights gap (where women's rights are very low in the origin) decreases in the gap may be associated with increases in the female brain drain ratio. However, starting from lower levels of the gap the relationship is positive: a greater gain in women's rights moving from origin to destination is, all else equal, associated with a greater 
likelihood of migration.

In addition to the ordinary least squares (OLS) results, we report that the relationship is robust to employing a Heckman (1970) two-stage regression approach or the Poisson pseudomaximum likelihood estimation suggested by Silva and Tenreyro (2006). Both of these approaches are utilized to deal with bilateral migration observations with a value of zero and ratios of flows that are undefined. These results are also qualitatively robust to controlling for the "multilateral resistance" (i.e., the influence of alternative destinations) that is emphasized by Bertoli and Fernández-Huertas Moraga (2012 \& 2013).

This organization of this paper is as follows. Section 2 contains a review of literature relevant to the present research. A theoretical model of migration choice is developed in section 3. This theory motivates the empirical model described in section 4; this section also overviews the data used to estimate that model. Estimation results are reported in section 5. Summary discussion appears in the concluding section 6.

\section{Previous Work on Female Migration, Female Brain Drain, and Women's Rights}

Brain drain is a widely explored topic in the context of development economics. (See Docquier and Rapoport (2012) for a review of the literature.) However, the gender aspect of brain drain has received relatively little attention; and that only recently. Furthermore, while the gender aspect of migration decisions has also received little attention, the role of women's rights in determining high-skilled female migration decisions has received almost none.

Dumont, Martin and Spievogel (2007) are the first researchers to provide data on genderspecific brain drain using OECD census databases for emigrants from 25 OECD and 79 nonOECD countries. They report that female brain drain rates from African countries tend to be 
notably higher than those of males. Alternatively, there is almost no brain drain gender gap when considering European origin countries. They also estimate the impact of female brain drain on the social and economic development of origin countries. They find that female brain drain ratios are positively and significantly related to infant mortality and under-five mortality; negatively and significantly related to female secondary school enrollment relative to males. They do not find similar harmful effects associated with the emigration of less-educated women. This suggests an important role for educated women in the health and education of children.

Docquier et al. (2009) provide a more extensive dataset for education- and genderspecific migration from 174 origin countries in 1990 and from 195 countries in 2000. Using this data, Docquier, Marfouk, Salomone, and Sekkat (2012) find that women respond differently than men to conventional "push" factors. For example, while male brain drain is negatively associated with an origin country's average human capital level, all else equal, the analogous relationship is positive in the case of women. Also, the distance from an origin country to the OECD area is negatively associated with male brain drain but positively associated with high-skilled female emigration. Relevant to the present research, Docquier et al. (2012) suggest that both of these anomalies may be related to gender discrimination.

Everything being equal, females would tend to migrate more because even with a college degree they may have difficulties to find an adequate job. The hidden discrimination would lead to some kind of positive selection that characterizes female migration. [Also] the positive sign of the coefficient of the distance to the OECD may reflect, especially for migrants originating from the South, the relatively lower discrimination in furthest OECD countries as compared to closer ones (p. 261). 
This suggests the importance of taking into account variation in women's rights as a determinant of female brain drain rates.

To our knowledge, Bang and Mitra (2011), Baudassé and Baziller (2011), Naghsh Nejad (2013) and Ferrant and Tuccio (2013) are the only other papers to empirically assess the role of women's rights and/or gender discrimination in determining female migration flows. Bang and Mitra (2011) attempt to proxy for "access to economic opportunities" and "economic outcomes" and report that only "opportunities" are related to female brain drain and the estimated relationship is a negative one. However, their "opportunity" variables include fertility rates and gender gaps in schooling and literacy. These variables might just as easily be interpreted as "outcomes".

Baudassé and Baziller (2011) use a principal components analysis (PCA) to aggregate various variables into indices of gender inequality, but only for 51 countries. ${ }^{3}$ They report that decreased gender inequality is associated with higher female migration rates and, in particular, higher rates for high-skilled females. Again, the variables employed in their PCA (e.g., the female employment rate and primary education ratio) can be interpreted as outcomes rather than institutional opportunities. In the present paper we utilize the CIRI women's rights indices. These indices are directly based on the economic rights (e.g., the right to work without a husband's consent), political rights (e.g., the right to vote), and social rights (e.g., the right to initiate a divorce) that women have in a given country. These rights are institutional and more clearly interpreted in terms of opportunities open to women.

Ferrant and Tuccio (2013) employ measures of discriminatory institutions from the OECD Development Centre and are, therefore, more closely related to the present study. They

\footnotetext{
${ }^{3}$ Baudassé and Baziller also use numbers of migrants rather than migration rates. Even though they do control for population on the right-hand-side of their empirical specifications, not using a rate of the dependent variable is inconsistent with the bulk of existing studies.
} 
examine bilateral migration flows, but only between non-OECD countries. They show that variation in their measure of discriminatory institutions is significantly related to female but not male migration. However, Ferrant and Tuccio do not focus on high-skilled migration (female brain drain) as we do in this paper.

Also, neither Ferrant and Tuccio (2013) nor Bang and Mitra (2011) and Baudassé and Baziller (2011) motivate their analyses with a formal model of how women's rights affect the costs and benefits of female migration decisions relative to those of males. None of these authors, then, derive the sort of non-linear relationship between women's rights and relative female migration rates that arises from our model in section 3 below. ${ }^{4}$ Our analysis, for example, offers a plausible reconciliation between the contradictory findings of Bang and Mitra (2011) and Baudassé and Baziller (2011). This reconciliation is based on acknowledging the fact that the extent of women's rights determines the relative costs, as well as benefits, to migration.

Naghsh Nejad (2013) does motivate her work with a similar theoretical model. She derives and estimates a nonlinear relationship between the female brain drain ratio and women's rights. However, she studies only migration flows from 195 non-OECD origins to OECD destinations. Her data set, then, is substantially smaller than that of the present paper: 345 total stocks of migrants in OECD countries versus over 3,000 bilateral migration flows. Importantly, she also cannot exploit the information in the women's rights differentials across OECD countries - nor the differentials involved with migration between non-OECD countries - as we do. Naghsh Nejad (2013) essentially assumes that all OECD countries are a benchmark in terms

\footnotetext{
${ }^{4}$ Baudassé and Baziller (2011) do argue that the effect of discrimination on female brain drain is theoretically ambiguous in terms of sign. Gender discrimination may increase the perceived benefits to migrating. Alternatively it may lead to a selection bias where a society's collective decisions concerning who is permitted to migrate are biased against females. Thus, gender discrimination may be a standard push factor or operate as a barrier to exit. However, Baudassé and Baziller (2011) do not allow in their empirical analysis for the sort of nonlinear relationship that logically follows from their own discussion. The same can be said of Ferrant and Tuccio (2013) who discuss the possible effects of discrimination on both the costs and benefits of migration but do not estimate a non-linear relationship.
} 
of women's rights. The focus of this paper is, instead, on the attractiveness of women's rights in particular destinations relative to particular origins.

None of the above studies control for the "multilateral resistance" that has been recently emphasized by Bertoli and Fernández-Huertas Moraga (2012 \& 2013). These authors argue that not only are the characteristics of a particular destination relative to an origin important for migration decisions, but also the characteristics of alternative destinations. Exploiting the large number of observations in our data, we check the robustness of our results to addressing multilateral resistance by including origin, destination, and origin-nest fixed effects in the estimations. The primary result is robust: the women's rights gap is significantly and nonlinearly related to the female brain drain ratio.

As we have stressed above, to our knowledge we are one of a handful of papers to focus on female brain drain in relation to women's rights. The relative dearth of research on women's rights in relation to female brain drain is an important shortcoming in the literature. Studies have suggested that, in general, gender inequality is harmful to a country's economic growth (e.g., Dollar and Gatti (1999) and Klasen (2000)). These studies suggest that a higher labor force participation rate of women contributes positively to economic development, a general view that is supported by the specific case studies of India and Sub-Saharan Africa by, respectively, Esteve-Volart (2004) and Blackden, Canagarajah, Klasen, and Lawson (2006). If gender discrimination is also associated with the flight of female human capital, this could another economically important channel through which gender inequality harms development. An important contribution of this paper is empirically asses how the provision of women's rights may also be indirectly related to economic development through its influence on female brain drain. 


\section{A Model of Migration Choice Facing Differences in Women's Rights}

We follow the random utility maximization (RUM) and extend the framework developed by Borjas (1987). We assume that individuals view a migration decision as a utility-maximization problem. Each individual makes her or his migration decision by computing the expected net gains associated with each possible location choice including their origin country (i.e., no migration).

However, in the neoclassical theory the role of gender has been largely neglected. This is surprising given the dissimilar migration patterns of men versus women in the data. After reviewing the literature, Pfeiffer, Richter, Fletcher, and Taylor (2007) suggest that "[s]eparate modeling approaches allowing for variables that differently affect migration benefits and costs for the sexes may be needed" (p. 18). This paper takes a step in this direction. Consider a model of migration with a single skill type (high-skilled). A high-skilled individual of gender $g$ ( $=m$ or f) living in country $i$ decides whether or not to migrate to some other country $j$ to maximize her or his utility. The individual's utility function if she or he stays in country $i$ is,

$$
u_{i i, g=W_{i}-D_{i, g}+\epsilon_{i j, g} .}
$$

$W_{i}$ is a deterministic component of utility function (that could be modeled as observable variables such as characteristics of the country that are gender-nonspecific). However, we also introduce the variable $D_{i, g}$ which represents the effects of institutionalized discrimination. Discrimination is inversely proportional to the level of women's rights provided in $i$. By assumption, $D_{i, g}=0$ for $g=m ; D_{i, g} \geq 0$ for $g=f$. Note that, for simplicity but without loss of generality, we assume that $W_{i}$ is the same for both women and men (i.e., any discrimination- 
based wage differentials are subsumed in $\left.D_{i, g}.\right)$ Lastly, $\varepsilon_{i j, g}$ is an individual-specific stochastic component of utility function.

The utility function of an individual from $i$ who migrates to country $j$ is,

$$
u_{i j, g=\gamma\left(W_{j}-C_{i j, g}-D_{j, g}\right)+v_{i j, g}}
$$

where $C_{i j, g}$ is the cost of migrating from country $i$ to $j$ and $v_{i j, g}$ is a shock similar to that in (1).

This costs include the monetary cost of moving, the opportunity cost of moving, the challenges of learning a new language, and the psychological cost of moving. ${ }^{5}$ More importantly for our purposes, we will assume below that these costs are, for women, a function of the origin country's level of discrimination. $D_{j, g}$ is the level of gender discrimination faced by the potential emigrant in $j$. Again by assumption, $D_{j, g}=0$ for $g=m ; D_{j, g} \geq 0$ for $g=f$.

As in Naghsh Nejad (2013) we introduce the assumption that the cost function is a strictly increasing convex function of discrimination in origin and destination countries:

$$
\begin{aligned}
& C_{i j, g}=C\left(T_{i j}, D_{i, g,}, D_{j, g}\right) \\
& \frac{\partial C_{i j, g}}{\partial D_{i, g}}>0 \\
& \frac{\partial^{2} C_{i j, g}}{\partial D_{i, g}^{2}}>0 \\
& \frac{\partial C_{i j, g}}{\partial D_{j, g}}>0 \\
& \frac{\partial^{2} C_{i j, g}}{\partial D_{j, g}^{2}}>0 \\
& \frac{\partial^{2} C_{i j, g}}{\partial D_{i, g} \partial D_{j, g}}>0
\end{aligned}
$$

\footnotetext{
${ }^{5}$ Beine and Salomone (2010) argue these costs can affect women and men differently. We here assume that the cost functions have identical forms for both men and women and, instead, look at how a lack of women's rights imposes different costs on men and women. This is not to argue against Beine and Salomone (2010). Rather we abstract from gender-specific cost functional form differences to focus on our question of interest.
} 
$T_{i j}$ represents factors (other than discrimination) that affect ones's migration costs. We assume increasing costs in both origin and destination country gender discrimination. In the case of origin country discrimination, this is plausible if, as discrimination increases (i.e., the level of women's rights decreases) the barriers to migration accumulate from primarily cultural norms (e.g., discouragement from family and friends) to norms and legal restrictions (e.g., difficulties in obtaining a passport) and then eventually to the lack of basic protections from threats of physical violence (e.g., it is legally and socially acceptable for a woman to be physically restrained by her husband). Sequentially each of these barriers seems to present increasingly large costs on the margin. Analogous arguments can be made for destination country discrimination levels. The same elements of a society that represent barriers to potential female emigrants also represent hardships to be borne by females immigrating to that society.

Based on the above assumptions, the net gain from moving from country $i$ to $j$ is,

$$
N G_{i j, g}=\gamma\left(W_{j}-W_{i}\right)+\gamma\left(D_{i, g}-D_{j, g}\right)-\gamma\left(C_{i j, g}\right)+\epsilon_{i j, g}
$$

An individual in $i$ will decide to move to a new country if (9) is positive for any $j$. Also, the individual will choose the destination that gives her or him the largest net gain, i.e., the $j$ for which (9) is largest. Assuming that $\epsilon_{i j, g}$ follows an independent and identically distributed extreme value type-1, based on McFadden (1984) the logged odds of migration from $i$ to $j$ is,

$$
\ln \frac{M_{i j}^{g}}{M_{i}^{g}}=\gamma\left(W_{j}-W_{i}\right)+\gamma\left(C_{i j, g}\right)+\gamma\left(D_{i, g}-D_{j, g}\right)
$$

Where $\frac{M_{i j}^{g}}{M_{i}^{g}}$ is the population share of gender group $g$ in $i$ that migrates to $j . M_{i}^{g}$ is the population share of gender group $g$ in $i$ that remains in $i$ Furthermore, the between female and male odds of migration is, 


$$
\ln \frac{M_{i j}^{f}}{M_{i}^{f}}-\ln \frac{M_{i j}^{m}}{M_{i}^{m}}=-\gamma\left(C_{i j, f}-C_{i j, m}\right)+\gamma\left(D_{i, f}-D_{j, f}\right) .
$$

Inspection of (11) gives us some intuition that motivates the empirical analysis below. There are two terms on the right-hand-side; one is negative and the other is positive. First, the positive term clearly expresses that, all else equal, the relative benefits to women considering migration from $i$ to $j$ are increasing in the amount of discrimination in $i$ relative to $j$. All else equal, the benefits to migration are higher when the move is towards a destination with a higher level of women's rights. On the other hand, the negative right-hand-side term concerns the relative costs of migration. Recalling, (3)-(7) above, the cost to females (relative to males) is increasing and convex in the discrimination in $i$ relative to $j$. For a given level of women's rights in $j$, a decrease in $i$ 's women's rights implies both increased costs and benefits to migration from $i$ to $j$. Because the costs are convex in discrimination, (11) will be a non-linear relationship in $\left(D_{i, f}-D_{j, f}\right)$.

Differentiating (11) separately with respect to discrimination levels in $i$ and $j$ yields,

$$
\begin{aligned}
& \frac{\partial}{\partial D_{i, f}}\left(\ln \frac{M_{i j}^{f}}{M_{i}^{f}}-\ln \frac{M_{i j}^{m}}{M_{i}^{m}}\right)=-\gamma\left(\frac{\partial C_{i j, f}}{\partial D_{i, f}}\right)+\gamma \quad \text { and } \\
& \frac{\partial}{\partial D_{j, f}}\left(\ln \frac{M_{i j}^{f}}{M_{i}^{f}}-\ln \frac{M_{i j}^{m}}{M_{i}^{m}}\right)=-\gamma\left(\frac{\partial C_{i j, f}}{\partial D_{j, f}}\right)-\gamma .
\end{aligned}
$$

Using the partial derivatives, (12) and (13), the total differentiation of (11) is,

$$
d\left(\ln \frac{M_{i j}^{f}}{M_{i}^{f}}-\ln \frac{M_{i j}^{m}}{M_{i}^{m}}\right)=\gamma\left(d D_{i, f}-d D_{j, f}\right)-\gamma\left(\frac{\partial C_{i j, f}}{\partial D_{i, f}} d D_{i, f}+\frac{\partial C_{i j, f}}{\partial D_{j, f}} d D_{j, f}\right) .{ }^{6}
$$

The first right-hand-side term is based on the expected benefits of migration and, by itself, confirms what might seem to be "common sense". When there is an increase in $i$ 's

\footnotetext{
${ }^{6}$ Note that there is no component of (14) including a partial derivative with respect to $T_{i j}$. Since, by assumption, a change in $T_{i j}$ has identical effects on male and female costs, its effect on relative migration rates is nil.
} 
discrimination relative to $j$, a woman's expected benefits in considering a move to $j$ increase. All else equal, this increases female migration from $i$ to $j$ relative to that of males. However, the second right-hand-side component of (14) is a cost component. An increase in $i$ 's discrimination relative to $j$ implies that $d D_{i, f}>0$ and/or $d D_{i, f}<0$. Consider the interesting case where, starting from an initial $D_{i, f}>D_{j, f}$, both of these inequalities hold and both $d D_{i, f}$ and $d D_{j, f}$ are small in absolute value. In other words, consider a migration opportunity from a country with fewer women's rights to one with more, and where the discrimination differential has become marginally more beneficial to women. On the cost side, higher discrimination in $i$ makes migration more costly $\left(-\gamma \frac{\partial C_{i j, f}}{\partial D_{i, f}} d D_{i, f}<0\right)$ which, all else equal, makes female migration less likely. Alternatively, lower costs due to less discrimination in $j\left(-\gamma \frac{\partial C_{i j, f}}{\partial D_{j, f}} d D_{j, f}>0\right)$ makes female migration more likely. Because costs are convex in both $D_{i, f}$ and $D_{i, g}$, at a relatively a high initial $D_{i, f}$ level, a negative effect will dominate the cost component and, possibly, (14) itself will be negative.

The nonlinear relationship derived from the model is perhaps more interesting if one considers why the "common sense" view that increasing women's rights may lead to less female brain drain. In a country that begins with a very low level of women's rights, increases in those rights may be associated with increases in female brain drain relative to that of males. This is because, on the margin, women's responses to the lower costs of leaving the country dominate the lesser benefits to migration. Our empirical analysis below is, to our knowledge, the one to explicitly incorporate and estimate this sort of nonlinearity.

\section{Data and Empirical Model}


Motivated by the theory in section 3, we now introduce the dependent and independent variables of our analysis. We also describe the gravity model and estimation techniques that we employ.

\subsection{Dependent Variable}

Our dependent variable is the relative female to male migration flow rates ${ }^{7}$ from country $i$ to country $j$ for each origin-destination pair in our sample. This variable is constructed from the Docquier et al.'s (2010) dataset and is constituted by cross-country census and register data. It includes both OECD and non-OECD countries for the years 1990 and $2000 .^{8}$

We record the proportion of migration flows from each origin country $(i)$ to each destination country $(j)$ as a percent of nationals of the origin country with the same level of education and gender in 1990. As for the number of nationals in each education and gender group we used the data from Docquier et al. (2009). ${ }^{9}$ The female brain drain ratio $(F B D R)$ is calculated as follows:

$$
F B R_{i j}=\frac{\text { female brain drain flow rate }}{i j}
$$

where the brain drain flow rates are,

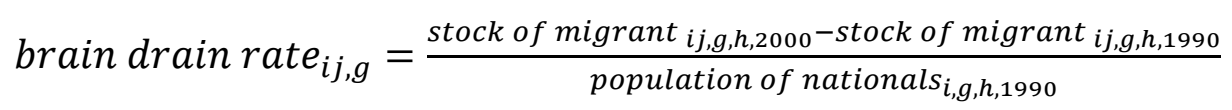

In (16), $g$ and $h$ refer to, respectively, gender and education level. The education level, $h$, that we focus on is high-skilled, i.e., individuals with post-secondary education.

\footnotetext{
${ }^{7}$ We use female to make flow rates, of migration instead of flows to control for the selection of migrants from origin countries.

${ }^{8}$ Docquier et al.'s (2010) focus on the population over the age of 25 in an attempt to exclude students from their data. Using this data one can identify immigrants based on country of birth rather than citizenship status, which is consistent over time.

${ }^{9}$ Docquier et al.'s (2009) report the number of all the nationals by summing the population residing in the origin country and the stock of migrants living abroad. They use population data from the CIA fact books and the United Nations.
} 


\subsection{Independent Variables}

Our independent variables of interest are the gap between origin and destination countries women's rights index values from the Cingranelli and Richards (2010) (CIRI) Human Rights Dataset. CIRI publishes three women's rights indices: women's social rights, women's economic rights, and women's political rights. Each of these indexes varies from 0 to 3 . A value of 0 implies that women's rights are not recognized at all by culture and law, and the degree of discrimination is high. A value of 3 implies that rights are fully recognized and enforced. For the intermediary values; a score of 1 implies very weak laws and weak enforcement; a score of 2 implies adequate laws but weak enforcement. Women's economic rights index take into account (i) the right to get and choose a job without a husband or male relative's consent; (ii) equalities in workplace hiring, pay, promotion, and job securities; (iii) protection from sexual harassment in the workplace; and (iv) the rights to work at night, in dangerous conditions, and in military and police forces. Women's political rights include the right to vote and engage in political activities such as running a political office, hold government positions, join political parties, and petition government officials. Women's social rights take into account (i) gender inequalities in inheritance, marriage, and divorce; (ii) rights to travel, obtain education, and choose a residence; and (iii) protection from genital mutilation and forced sterilization.

In our analysis we initially calculate a comprehensive women's rights variable by adding the three different indexes from the CIRI dataset. We add one to each component so that each varies between one and four. ${ }^{10}$ This prevents denominator (and, for that matter, numerator)

\footnotetext{
${ }^{10}$ Alternatively, we also estimate the results by constructing the women's rights variables in origin and destinations by adding women's social, economic and political rights in their origin form. The only origin country with women's rights levels of zero is Afghanistan which is dropped from the estimation. The results are presented in table A2 in appendix 1 .
} 
values from being zero. The comprehensive women's rights gap between an origin country, $i$, and a destination country, $j$, is then calculated at the ratio of the $j$ value to the $i$ value ${ }^{11}$ :

$$
\begin{aligned}
& \text { Women's Rights Gap } i j= \\
& \frac{\text { Women's Economic Rights }_{j}+\text { Women's Political Rights }_{j}+\text { Women's Sociall Rights }_{j}}{\text { Women's Economic Rights }} \text { Women's Political Rights }_{i}+\text { Women's Social Rights }_{i}
\end{aligned}
$$

Both the numerator and denominator of (17) can vary from 3 to 12 ; the range of the ratio is therefore from 0.25 to 4.00 .

The comprehensive women's rights gap, (17), assumes equal weighting of all three dimensions of women's rights - economic, social, and political. This assumption can, of course, be questioned. As well, we would like to know which dimensions of women's rights are most important for determining the female brain drain ratio. Still, including measures of all three dimensions separately introduces collinearity and may inflate standard errors. Faced with this, we proceed by first reporting estimations that include the comprehensive index. Subsequently, we report results using the three constituent components:

$$
\begin{aligned}
& \text { Women's Economic Rights Gap }{ }_{i j}=\frac{\text { Women's Economic Rights }_{j}}{\text { Women's Economic Rights }_{i}} \\
& \text { Women's Political Rights Gap }{ }_{i j}=\frac{\text { Women's Political Rights }_{j}}{\text { Women's Political Rights }_{i}} ; \\
& \text { Women's Social Rights Gap }_{i j}=\frac{\text { Women's Social Rights }_{j}}{\text { Women's Social Rights }_{i}}
\end{aligned}
$$

Again, we are using CIRI index values plus one. This prevents denominators from being zero and implies maximum values for the gaps of 4.00 and minimum values of 0.25 .

In addition to our women's rights variables of interest, we control for various other variables including, first, origin and destination countries' GDP per capita. GDP per capita is

\footnotetext{
${ }^{11}$ Alternatively, we also estimate the results by constructing the women's rights' gap variable as a subtraction between the women's rights levels in origin from the women's rights levels in destination. The results are presented in Table A1 in appendix 1. The results that we report below are not different qualitatively from those found in Table A1.
} 
from the World Bank. ${ }^{12}$ In the neoclassical model of migration higher origin GDP per capita is associated with weaker incentives to migrate. Likewise, higher destination GDP is considered to be an important "pull” factor for migration. Dumont et al. (2007) also report that high-skilled women are more responsive to levels of GDP than are men. For similar reasons we control for both origin and destination unemployment rates. Unemployment rate data comes from the World Bank. ${ }^{13}$ A high level of origin unemployment in a source country is likely to "push" migrants away; a low destination unemployment rate is then likely to "pull" them towards that destination. Furthermore, we control for an origin countries' political stability. This variable is from the World Bank governance indicators and the likelihood that the government loses its power by internal terrorism or other violent means. ${ }^{14}$ This score varies between -2.5 and 2.5. A higher score indicates a more stable government.

Several geographic characteristics of origin and destination countries are also included in our gravity model estimations. We include a landlocked dummy variable from Mayer and Zignango (2011) that takes a value of 1 if a country is landlocked and 0 if it is not. Countries that are "geographically disadvantaged" are isolated and tend to have lower migration flows (Docquier, et al., 2012). Also from Mayer and Zignango (2011) we include a small island dummy (1 = small island; 0 otherwise). Small islands tend to have significantly higher rates of emigration. Docquier (2006) reports typically higher brain drain rates from small islands.

Finally, we include several origin-destination specific cost factors. Following Mayer and Zignago (2011) we include a contiguity dummy to capture the effect of being geographic neighbors. We control for the bilateral distance between country pairs (defined as the geodesic

\footnotetext{
${ }^{12}$ This comes from the World Bank national accounts data and OECD national accounts data files: http://data.worldbank.org.

${ }^{13}$ This comes from the World Bank Key Indicators of the Labour Market database: http://data.worldbank.org.

${ }^{14}$ http://info.worldbank.org/governance/wgi/sc country.asp
} 
distances between the major cities). We also include a colony dummy that takes the value of 1 for country pairs that have a past colonial relationship; 0 otherwise. Colonial relationships between country pairs can lower migration costs. First, countries with colonial links are more likely to have similar cultures, religions, education systems, and other institutions. Colonizer countries also tend higher stock of migrants from their former colonies. These similarities lead to lower transition costs for migrants. Moving into a country with a similar education system can make finding a job easier because the likelihood of one's documentation and skill sets being accepted is higher. Cultural similarities also make the transition process easier. Having a network of previous migrants from one's origin can reduce monetary and non-monetary costs of migration. Finally, we include two common language dummy variables. A common language dummy takes the value of 1 if $20 \%$ or more of the population in the origin and destination countries speak the same language. A common second language dummy takes the value of 1 if more than 9 but less than $20 \%$ of the populations speak a same language.

We use the average of 1990 and 2000 data for control variables. However, we subsequently check the robustness of our results to using "initial" 1990 values for independent variables. Table 1 contains summary statistics for all variables included in our analysis.

\subsection{Gravity Model and Estimation Techniques}

The gravity models that we estimate are each of one of three forms:

$$
\begin{aligned}
& \log \left(F B R_{i j}\right)=\beta_{0}+\beta_{1}\left(\text { Women's Rights Gap }_{i j}\right)+\beta_{2}\left(\text { Women's Rights Gap }_{i j}\right)^{2}, \\
& +\bar{\beta}_{Z} Z_{i j}+\varepsilon_{i j} \\
& \log \left(F B R_{i j}+1\right)=\beta_{0}+\beta_{1}\left(\text { Women's Rights Gap }_{i j}\right)+\beta_{2}\left(\text { Women's Rights Gap }_{i j}\right)^{2}, \\
& +\bar{\beta}_{Z} Z_{i j}+\varepsilon_{i j}
\end{aligned}
$$


or

$$
\begin{aligned}
& F B R_{i j}=\beta_{0}+\beta_{1}\left(\text { Women' s Rights Gap }_{i j}\right)+\beta_{2}\left(\text { Women's Rights Gap }_{i j}\right)^{2} \\
& +\bar{\beta}_{Z} Z_{i j}+\varepsilon_{i j}
\end{aligned}
$$

where $F B R_{i j}$ and the Women's Rights Gap $i j$ are defined according to (15) and (17) above; $Z_{i j}$ contains our other control variables. We estimate (21) using both OLS and the Heckman (1970) two-stage regression approach. Since multiple observations taking the value of zero is an issue with migration data, we also estimate (22) by OLS. The addition of 1 to the dependent variable allows us to include (logged) observations where $F B R_{i j}$ is equal to zero. However, observations where $F B R_{i j}$ is undefined (when the male migration flow in the denominator is zero) are still excluded. We also apply the Poisson pseudo-maximum likelihood estimation suggested by Silva and Tenreyro (2006) to (23).

Our approaches to handling the problem of a large number of zero and undefined $F B R_{i j}$ values deserves some attention here. If zeroes are randomly distributed then dropping them in OLS estimation of (21) is correct. (In that case the zeroes are not informative.) However, the observations may indeed contain useful information and, in that case, discarding them can lead to inconsistent estimates (Silva and Tenreyro, 2006). For example, a zero female migration rate may signal that migration is prohibitively costly due to severe gender discrimination in either the origin or destination country. Alternatively, an undefined female brain drain ratio (e.g., no female or male migration) may indicate generally high migration costs between an origin and destination pair. In either case, discarding both the zero and undefined female brain drain ratios may be discarding useful information.

To overcome this problem, first we follow a traditional approach by simply adding 1 to the dependent variable and then applying OLS to (22). This solution is ad hoc and there is no 
guarantee that estimation results based on it reflect the true underlying relationships. Also, since our dependent variable is a ratio of migrations flows, in our analysis zero migration flow observations translate into dependent variable observations that may be zero or may be undefined. The latter observations will still end up discarded.

Another alternative approach is Heckman's (1970) two-stage estimation of (21). Heckman considers both the missing (for us, undefined) and zero observations as a self-selection issue. It is plausible that the probability of having non-zero migration between two countries is correlated with unobserved characteristics of that country pair. In a Heckman estimation, the first step is the probit estimation of (21) to determine, based on the conditioning variables, the probability of a non-zero, defined dependent variable observation. Then in a second stage OLS regression of (21), the expected values from the first-stage probit estimation are used in place of the undefined and zero dependent variable observations,

Wooldridge (2002) argues that using the same sets of variables in the probit model is acceptable and Beine, Docquier, and Özden (2011) show that their result stays consistent when they use the same set of variables or when they use an instrumental variable to predict the possibility of having a migration flow between countries. Here, we use the same sets of variables for the first stage of Heckman model. Here we assume the probability of observing a positive migration flow or female brain drain ratio is correlated with observing a positive stock of migration from country $i$ in country $j$ in year 2000. The Heckman estimation creates an inverse Mills Ratio from the first stage estimation (estimated expected error) based on the parameters estimates. Then, it uses the inverse Mills Ratio as an additional regressor in the second stage OLS estimation of (21). In a way the Heckman estimation removes the part of the error term 
correlated with this regressor. The Heckman model is the most comprehensive in terms of taking the maximum number of observations into account.

Yet another approach that we employ is the Poisson pseudo maximum likelihood method suggested by Silva and Tenreyro (2006). PPML estimates directly the nonlinear form of the gravity model, (23), and avoids dropping zero dependent variable observations. In other words, PPLM avoids needing to take the natural log of the dependent variable. Silva and Tenreyro (2011) argue that the Poisson pseudo maximum likelihood estimation is robust to the presence of large number of zeroes in the data. Moreover, they argue that while the traditional gravity model is biased in the presence of heteroskedasticiy and log linearization leads to inconsistent estimates, the Poisson pseudo maximum likelihood estimation is consistent with the assumptions of the underlying RUM model. However, the Poisson pseudo maximum likelihood estimation, like OLS estimation of (22), excludes undefined values of the female brain drain ratio. The Heckman estimation is the only method that treats the zero migration flows as unobserved rather than nonexistent. While both PPML and Heckman have strengths and weaknesses, our main findings turn out to be qualitatively independent of which of the two estimation methods is employed.

\section{Results}

Tables 2 through 7 report our empirical results. Each table reports (I) OLS estimates based on $\log \left(F B R_{i j}\right)$ as the dependent variable, (II) OLS estimates based on $\log \left(F B R_{i j}+1\right)$ as the dependent variable, (III) Heckman two-stage estimates, (IV) PPML estimates, and (V) PPML estimates based only on values of $F B R_{i j}$ that are positive. All estimations include a women's 
rights gap variable and that variable's squared value as regressors. As a way of summarizing, the results reported below in advance.

- A statistically significant, non-linear relationship between the female brain drain ratio and the comprehensive women's rights gap is estimated across all specifications.

- The relationship is robust to using 1990-2000 averages or initial 1990 values of control variables.

- The inverse Mills ratio enters significantly (5\% level) in the second stage of the eight different estimations which evidences the existence of sample selection bias.

- Based on estimations including one rights gap measure at a time, a statistically significant non-linear relationship is estimated across all specifications for both political and social women's rights gaps; the non-linear relationship for the economic women's rights gap is statistically significant in all specifications except for PPML.

- Including all three rights gaps measures in single estimations yields a statistically significant nonlinear relationship for the women's political rights gap across specifications; the relationship for the women's economic rights gap is statistically significant in all specifications except for PPML.

- All statistically significant estimated relationships imply that, starting from low levels of the women's rights gap, increases are associated with greater relative female brain drain on the margin; at higher levels of women's rights the relationship becomes positive.

- Despite a large loss in degrees of freedom, the non-linear relationship between the women's rights gap and the female brain drain ratio is robust to controlling for multilateral resistance (Bertoli and Fernández-Huertas Moraga (2012). 
As indicated above, we report estimations including one type of women's rights gap (and its squared value) at a time (tables $4,5, \& \mathbf{6}$ ) and also estimations including all three types simultaneously (table 7). In the case of the former estimations, the excluded women's rights variables may be omitted variables that are correlated with the included variables, biasing the estimates. Alternatively, including all three types of rights at once is likely to introduce collinearity, yielding imprecise estimates. Our compromise is to report on both, having noted the caveats to each.

\subsection{Comprehensive Women's Rights Gap}

Column I of table 2 shows the results of the benchmark OLS estimation. The women's rights gap variable enters positively and significantly at the $1 \%$ level; its squared value enters negatively and significantly also at the $1 \%$ level. This nonlinear, "hump-shaped" relationship peaks at a women's rights gap value of about 1.796. A value of 1.796 is more than a sample standard deviation greater than the sample mean (1.193). It implies a large gap in women's rights in favor of the destination country. For example, gap values in our sample greater than 1.796 would correspond to Saudi Arabia, Lesotho, and Sudan as origins relative to the US as a destination. As an alternative example, the ratio of the US women's rights index to that of Nigeria $1.636<1.796$.

Starting from a women's rights gap value of less than 1.796, the OLS estimates suggest that increases in an origin country's women's rights, relative to those of the destination country, will decrease the relative amount of female brain drain. This would apply to most of the origindestination pairs in our sample. We also believe that it is the "common sense" result, i.e., at first consideration one is likely to conjecture that the more relatively desirable the destination 
country's women's rights, the greater the high-skilled female migration to that destination will be.

However, while "relatively desirable" implies the benefits of the destination relative to the origin, there are also the costs of migration to be taken into account. The OLS estimates suggest that, starting from women's rights gap values greater than 1.796 , increases in that gap will be associated with decreases in female brain drain from the origin to the destination. Interpreted in terms of our theoretical model in section 3 above, starting from a high gap value the women's rights in the destination country are very good and/or those in the origin country are exceedingly poor. If the gap widens, in terms of the cost component of equation (14), the costs associated with leaving the origin country increase and/or those associated with entering the destination country decrease. If both the origin and destination costs are convex (partial derivatives (6) and (7)), then it is the former effect that likely dominates the estimated effect. A decrease in origin country's women's rights imposes large marginal increases to the costs associated with a high-skilled female leaving. Therefore, starting from very high women's rights gap values (especially from exceedingly poor origin country women's rights levels) this cost effect dominates.

The OLS results from column I exclude (log) female brain drain ratios observations that are zero because of a zero numerator. Column II reports OLS results that incorporate the latter (an additional 353 observations) by adding one before taking the natural log. The results for the women's rights variables of interest are qualitatively unchanged. Furthermore, while the coefficient estimates on women's rights gap and its squared value are quantitatively different, they imply a threshold value of 1.763 , almost identical to that implied by the column I estimates. 
Column III contains the results of the Heckman estimation. This approach allows us to incorporate information from another 743 undefined observations where the denominator or both numerator and denominator of the female brain drain ratio are zero. The inverse Mills ratio enters significantly (5\% level) in the second state estimation. This is evidence that selection bias is important when the undefined/zero observations are excluded. The Heckman coefficient estimates on the women's rights gap and gap squared are both statistically significant (5\% level or better). Furthermore, they are almost indistinguishable from the column I, OLS results; they imply a threshold women's rights gap value of 1.795. Starting from only from very high women's rights gap values, increases in the gap between destination and origin countries are associated with decreases in the female brain drain ratio. Again, the result implies that, for most origin-destination pairs in our sample, increasing (decreasing) women's rights in origin (destination) country decreases the relative number of high-skilled women migrating from the origin to the destination.

To check the robustness of this result, columns IV and V report results from the estimation of (23) using the Poison pseudo maximum likelihood (PPML) method suggested by Silva and Tenreyro (2011). Whether using all values of the female brain drain ratio (column IV) or just the positive value (column V) the results are qualitatively similar to those from the Heckman estimation. All relevant coefficient estimates are statistically significant (10\% level or better) but smaller in absolute values compare to the Heckman two stage specification or the OLS estimations. This is consistent with Silva and Tenreyro (2011). The threshold women's rights gap levels are actually slightly higher at 1.934 and 1.998 for columns IV and V, respectively. This might arise from the fact that the PPML model cannot take into account the 
presence of undefined values of the dependent variable. Regardless, the thresholds are still quite high relative to the women's rights gap sample mean (1.193).

As a robustness check we also used the data from 1990 for explanatory variables rather than the average of 1990 and 2000 data. As it can be seen in table 3 the results are very similar. Specifically, from our preferred Heckman results (column III) the coefficients on both the women's rights gap and its squared value are statistically significant at the $1 \%$ level. As before, the former point estimate is positive and the latter is negative. The implied threshold women's rights gap value is 1.943. (The inverse Mills ratio enters significantly in the second stage regression.)

\subsection{Economic, Political, and Social Rights Gaps Separately}

Lumping economic, political, and social rights into one comprehensive measure might be inappropriate. Therefore we proceed to allow different (nonlinear) effects to be associated with different rights components. We first consider separate specifications including, respectively, women's economic, political, or social rights gaps. These results are contained in, respectively, tables 4,5 , and 6 . In each case, omitting the other two rights components may lead to omitted variable bias. Alternatively, introducing all three individual rights gaps (and their squared values) in a single specification may lead to inflated standard errors due to collinearity. We will explore whether that is the case in the following section 5.3.

Tables 4, 5, and $\mathbf{6}$ present the results of estimation using, separately and respectively, women's economic, political, and social rights gaps along with their squared values as regressors. The women's economic rights gap and its squared value each remain statistically significant at the $1 \%$ level in both of the OLS regressions (table 4; columns I \& II) and the 
Heckman estimation (column III). The point estimate on the gap level is always positive; on its squared value it is always negative. Focusing on our preferred Heckman estimation results, the positive effect of changes in the women's economic rights gap on the female brain drain ratio turns negative at around a gap value of 2.076 while the mean of this variable is 1.213 in our data. However, in both of the PPML estimations (columns IV \& V) neither the women's economic rights gap nor its squared value enters significantly. We must conclude that the table 4 results based on the women's economic rights gap are not as robust to estimation technique as those reported in table 2 using the general women's rights index values.

On the other hand, the women's political rights gap and its squared value enter significantly into both of the OLS regressions (table 5; columns I \& II), the Heckman estimation (column III), and both of the PPML estimations (columns IV \& V). The signs of the point estimates are always positive and negative, respectively. Based on the Heckman results, starting from any women's political rights gap level below 1.935, increases in the gap between the destination and origin countries' rights levels are associated with increases in relative female brain drain towards the destination country. Starting from higher gap levels the estimated effect is negative. This is a robust result across estimation techniques and is consistent with the intuition described in regards to the table 2 results.

The table 5 results, concerning women's social rights gaps, are qualitatively the same as those reported in table 5. The now-familiar, non-linear "hump-shaped" relationship appears significantly across of estimation techniques. The threshold women's social rights gap value (based on the column III Heckman results) is higher (2.422) than reported for the other types of rights gaps. However, the sample mean of the women's social rights gap is also higher (1.345) than that associated with economic (1.213), political (1.063), or general (1.193) rights. 
The common result across tables 4, 5, and $\mathbf{6}$ - which is robust for both women's political and social rights - is that, for most origin and destination country pairs in our sample, increasing women's rights in origin country decreases the relative number of high-skilled women migrating away from the origin country and towards the destination. Only starting from exceptionally high women's rights gap values (and, presumably, when the origin country has exceedingly poor definition and enforcement of women's rights) do we find that increases in the gap are associated with decreases in the female brain drain ratio. Intuitively, even though increases in the gap make migration more beneficial, they also make it more costly and this latter effect dominates.

\subsection{Economic, Political, and Social Rights Gaps Simultaneously}

Table 7 reports the results of estimations including women's economic, political, and social rights gaps (along with their squared values) as independent variables simultaneously. The first thing to note is that, across estimation techniques, whenever a gap variable is statistically significant, it carries the sign that we would expect given the results already reported on above; the "hump-shaped" relationship manifests itself.

The political rights gaps and the squared values are statistically significant, always at the $1 \%$ level, in both OLS regressions (columns I \& II), the Heckman estimation (column III), and both PPML estimations (columns IV and V). Using the preferred Heckman results, the threshold women's political rights gap value is 2.562 . This nonlinear effect associated with the women's political rights gap is, overall, the most robust finding that we report. The women's economic rights gap and its squared value are again significant in all but the two PPML estimations. The threshold economic rights gap value implied by the Heckman results is 2.194. Apparently, the women's social rights gap is the weakest candidate in our estimations. When included along with 
the economic and political rights gaps it only enters significantly (5\% level) in the PPML estimation using positive female brain drain ratio values only (column V). Even then its squared value enters insignificantly (though the point estimate remains negative).

\subsection{Controlling for Multilateral Resistance}

Bertoli and Fernández-Huertas Moraga (2012 \& 2013) show that PPML estimation of gravity models results in consistent estimates if there is no cross-observation dependence (what these authors refer to as (multilateral resistance). However, if individuals from a certain country of origin have specific preferences for a destination or a group of destinations, then this multilateral resistance can result in biased estimated.

We control for multilateral resistance by following Bertoli and Fernández-Huertas Moraga (2012). These authors suggest including origin and destination fixed effects, as well as origin-nest fixed effects. The inclusion of these origin nest dummies satisfies the cross dependence requirement for PPML estimation. Intuitively, when we observe migration from a particular origin to a particular destination, we are controlling for the fact that individuals from that origin may have different preferences across groupings of destinations. For example, individuals from Sub-Saharan African may, all else equal, prefer destinations in a Latin America over destinations in Asia; and they may prefer destinations in the Asia over those in Western Europe. $^{15}$

We divide the origin countries to four groups (nests): (i) Western democracies and former Soviet Union countries, (ii) Asian, Middle Eastern, and North African countries, (iii) SubSaharan African countries, and (iv) Latin American countries. The lists of countries that are

\footnotetext{
${ }^{15}$ This rank ordering is purely fabricated for the purposes of illustration. It is based on no evidence whatsoever and makes not even the remotest claim to plausibility.
} 
included in each nest are given in table 8. This is by no means an ideal classification and, all else equal, it would be desirable to break (i) through (iv) up into a greater number of nests. However, a difficulty with employing the Bertoli and Fernández-Huertas Moraga (2012) approach is that many degrees of freedom that are lost by including a very large number of dummy variables (1,030 dummies to be exact). Four nests are the maximum for which we are able achieve some statistically significant results while attempting to control for cross-sectional dependence. Because we account for considerable heterogeneity with these fixed effects we drop all of the other (non-women’s rights gap) control except for the common first language and colony dummies, and the (log) distance variable (as do Bertoli and Fernández-Huertas Moraga, 2012).

In table 9 we report PPML estimations along these lines. Columns I, II, III, and IV contain results based on, respectively, comprehensive, economic, social, and political women's rights gaps. For the comprehensive women's rights gap, both it and its squared value enter significantly (5\% and $10 \%$ levels, respectively). Quantitatively the effects are not significantly different than those reported in column IV of table 2. The estimated effects are similarly statistically significant for the economic rights gap (column II). (Note that the PPML estimated effects from table 4 column IV were not statistically significant.) The results regarding social and political rights gaps (columns III and IV) are not statistically significant, though they remain qualitatively consistent with the sort of non-linear relationship that has manifested itself throughout the results.

Evaluating the table 9 results vis-à-vis the results from previous tables is not straightforward. The results are qualitatively significant throughout. Alternatively, the PPML results are always based on excluding observations where ratios are not defined. Furthermore, controlling for multilateral resistance involves the inclusion of 1,030 dummy variables and for 
estimation based on at most 3,354 observations. We believe that that the takeaway from table 9 is twofold. First, the non-linear relationship between the female brain drain ratio and the comprehensive women's right gap is exceptionally robust. Second, the pattern of point estimates on all women's rights gaps (economic, social, and political) and their squared values is qualitatively unchanged when controlling for multilateral resistance.

\section{Conclusion}

We explore women's rights as a determinant of the female brain drain rate relative to that of men (the female brain drain ratio). We develop a model of migration where both women's expected costs and benefits of migration are a function of women's rights in the origin country relative to those of the destination (the women's rights gap). Since both costs and benefits are a function of the women's rights gap, the relationship between changes in that gap on the female brain drain ratio is nonlinear. In particular, starting from high values of the rights gap, increases in the relative level of rights in the origin country can be associated with increases in the female brain drain ratio. However, starting from lower levels of the gap the relationship turns negative. In other words, when women's rights levels are higher in the destination country in comparison with the origin country, high-skilled women are more likely to migrate (compare to men), unless the low levels of women's rights in origin manifests as increased cost of migration for women.

Using a cross section of over 3,000 bilateral migration flows across OECD and nonOECD countries and the women's rights indices from the CIRI Human Rights Dataset, we report evidence consistent with the theory. A statistically significant and nonlinear relationship exists between women's rights gaps and female brain drain ratios. The results are consistent across different estimation techniques and different measures of the women's rights gap variable. They 
are also qualitatively robust to controlling for multilateral resistance. We use the gap in women's economic, political and social rights as well as a comprehensive variable that consist of all the three variables The evidence is particularly strong for the case of women's political rights.

Despite the non-linear relationship that we estimate, we believe that the policy implications are linear: countries can enhance their prospects for economic development by promoting more extensive women's rights. For a given origin, only from very low initial values of women's rights relative to potential destinations will increases in women's rights be associated with more female brain drain. However, as reviewed in the introduction, severe deficiencies in women's rights are, in and of themselves, associated with large losses in terms of development outcomes (e.g, Abu-Ghaida and Klasen, 2004). To wit: starting from low initial levels of rights, the cure for female brain drain is more costly than the disease. Alternatively, for most countries marginal increases in women's rights can meaningfully shift incentives towards high-skilled females forgoing migration and contributing to their country's development. 


\section{References}

Abu-Ghaida, D., Klasen, S. 2004. The costs of missing the millennium development goal on gender equity. World Development 32, 1075-1107.

Bang, J.T., Mitra, A. 2011. Gender bias and the female brain drain. Applied Economics Letters $18,829-833$.

Baudassé, T., Bazilier, R. 2011. Gender discrimination and emigration: push factor or selection process? http://remi.bazillier.free.fr/baudasse_bazillier_gender.pdf.

Behrman, J. R., Deolalikar, A. B. 1988. Health and nutrition. in Chenery and Srinivasan (eds) Handbook of Development Economics, Volume I, North-Holland, Amsterdam.

Beine, M.A., Docquier, F., Özden, C. 2011. Diasporas. Journal of Development Economics 95, $30-41$.

Beine, M.A., Salomone, S. 2011. Network effects in international migration: education versus gender. Center for Research in Economic Analysis Discussion Paper Series 11-08

Bertoli, Simone \& Fernández-Huertas Moraga, Jesús, 2012. "Visa Policies, Networks and the Cliff at the Border," IZA Discussion Papers 7094, Institute for the Study of Labor (IZA).

Bertoli, Simone \& Fernández-Huertas Moraga, Jesús, 2013. "Multilateral resistance to migration," Journal of Development Economics, Elsevier, vol. 102(C), pages 79-100.

Blackden, M., Canagarajah, S., Klasen, S., Lawson, D. 2006. Gender and growth in Sub-Saharan Africa: issues and evidence. WIDER Research Paper No. 2006-37.

Borjas, G.J. 1987. Self-selection and the earnings of immigrants. American Economic Review 77, 531-553.

Cingranelli, D. L., Richards, D. L. 2010. The Cingranelli-Richards (CIRI) Human Rights Dataset. Version 2010.05.17. 
Docquier, F. 2006. Brain drain and inequality across nations. IZA Discussion Paper No. 2440.

Docquier, F., Lowell, B. L., Marfouk, A. 2009. A gendered assessment of the brain drain. Population and Development Review 35, 297-321.

Docquier, F., Marfouk, A., Salamone, S., Sekkat, K. 2012. Are skilled women more migratory Than skilled men? World Development 40, 251-265.

Docquier, F., Rapoport, H. 2012. Globalization, brain drain and development. Journal of Economic Literature (forthcoming).

Dollar, D., Gatti, R. 1999. Gender inequality, income, and growth: are good time good for women? Policy Research Report on Gender and Development, Working Paper Series, No. 1, World Bank.

Dumont, J.C., Martin, J.P., \& Spielvogel, G. 2007. Women on the move: the neglected gender dimension of the brain drain. IZA Discussion Papers No. 2920.

Esteve-Volart, B. 2004. Gender discrimination and growth: theory and evidence from India. Working Paper, Suntory and Toyota International Centres for Economics and Related Disciplines, London School of Economics.

Ferrant, G., Tuccio, M. 2013. South-South Emigration and Discriminatory Social Institutions: a Two-Way Relationship. Working Paper.

Grogger, J., Hanson, G.H. 2011. Income maximization and the selection and sorting of international migrants. Journal of Development Economics 95, 42-57.

Klassen, S. 2000. Does gender inequality reduce growth and development? evidence from crosscountry regressions. Policy Research Report on Gender and Development, Working Paper Series, No. 7, World Bank.

Knowles, K., Lorgelly, P. K., Owen, P. D. 2002. Are educational gender gaps a break on 
economic development? some cross-country empirical evidence. Oxford Economic Papers 54, 118-149.

Mammen, K., Paxson, C. 2000. Women's work and economic development. Journal of Economic Perspectives 14, 141-164.

Mayer, T., Zignago, S. 2011. Notes on CEPII's distances measures (GeoDist). CEEPII Working Paper 2011-25 (www.cepii.fr/anglaisgraph/bdd/distances.htm).

McFadden, D.L. 1984. Econometric analysis of qualitative response models. in Handbook of Econometrics, Elsevier.

Naghsh Nejad, Maryam, 2013. "Institutionalized Inequality and Brain Drain: An Empirical Study of the Effects of Women's Rights on the Gender Gap in High-Skilled Migration," IZA Discussion Papers 7864, Institute for the Study of Labor (IZA).

Pfeiffer, L., Richter, S., Fletcher, P., Taylor, J.E. 2007. Gender in economic research on international migration and its impacts: a critical review. in Morrison, Schiff, and Sjöblom (eds) The International Migration of Women, Palgrave McMillan and the World Bank, New York.

Schultz, T. P. 1988. Education investments and returns. in Chenery and Srinivasan (eds) Handbook of Development Economics, Volume I, North-Holland, Amsterdam.

Silva, J. M., Santos, C., Tenreyro, S. 2006. The log of gravity. Review of Economics and Statistics 88, 641-658.

Subbarao, K., Raney, L. 1995. Social gains from female education: a cross-national study. Economic Development and Cultural Change 44, 105-28. 
Figure 1.

Brain drain gender gaps on each major continent.

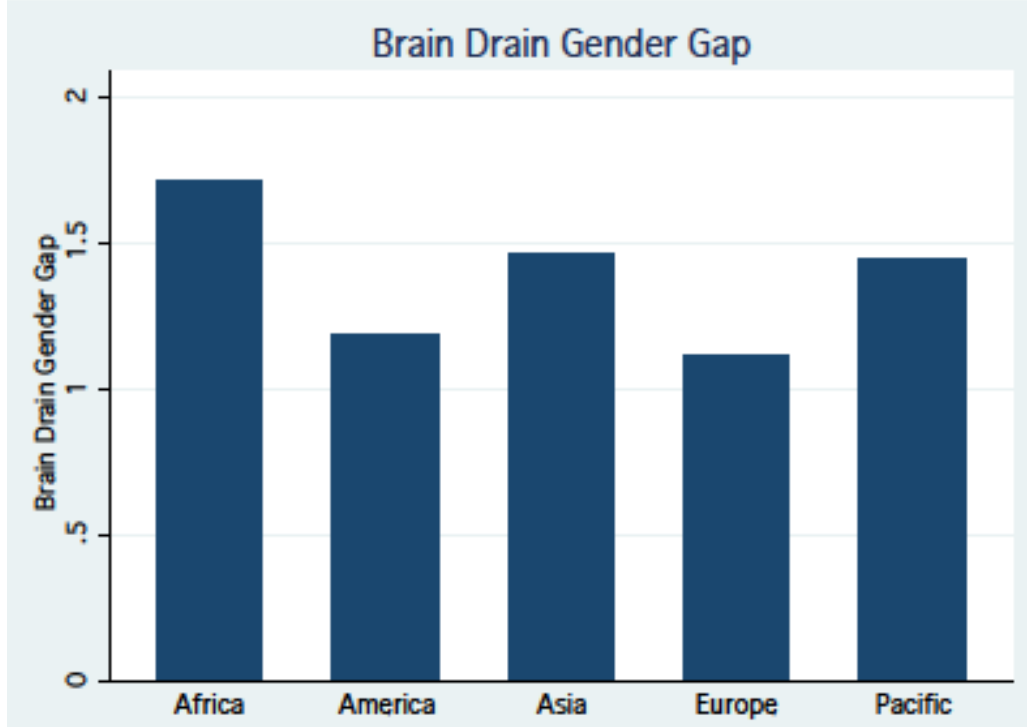

Note: data are from Docquier et al. (2009). 
Table 1. Summary statistics of variables included in estimations.

\begin{tabular}{|c|c|c|c|c|c|}
\hline & $\min$ & $\max$ & mean & Standard deviation & Observations \\
\hline Landlocked dummy & 0.000 & 1.000 & 0.198 & 0.399 & 172 \\
\hline Small Island dummy & 0.000 & 1.000 & 0.348 & 0.348 & 172 \\
\hline Contiguity dummy & 0.000 & 1.000 & 0.062 & 0.241 & 5001 \\
\hline Common first* language dummy & 0.000 & 1.000 & 0.184 & 0.387 & 5001 \\
\hline Common second language dummy & 0.000 & 1.000 & 0.191 & 0.393 & 5001 \\
\hline Colony dummy & 0.000 & 1.000 & 0.040 & 0.195 & 5001 \\
\hline Distance & 35.591 & 19649.830 & 6132.615 & 4627.423 & 5001 \\
\hline Log distance & 3.572 & 9.886 & 8.331 & 1.010 & 5001 \\
\hline Unemployment rate & 0.450 & 43.500 & 9.660 & 7.279 & 149 \\
\hline Government stability & 0.223 & 0.603 & 0.290 & 0.084 & 149 \\
\hline Polity & -10.000 & 10.000 & 2.232 & 6.596 & 125 \\
\hline Female brain drain flow rates & 0.000 & 23.333 & 0.025 & 0.353 & 6605 \\
\hline Male brain drain flow rates & 0.000 & 4.533 & 0.010 & 0.113 & 6605 \\
\hline Female Brain Drain Ratio & 0.00 & 49.971 & 2.194 & 3.111 & 5,268 \\
\hline Log(Female Brain Drain Ratio) & -5.728 & 3.911 & 0.497 & 0.893 & 4,671 \\
\hline Log GDP & 5.040 & 10.592 & 7.563 & 1.490 & 171 \\
\hline Women's social rights & 1.000 & 4.000 & 2.201 & 0.715 & 144 \\
\hline Women's political rights & 1.000 & 4.000 & 2.752 & 0.581 & 141 \\
\hline Women's economic rights & 1.000 & 3.500 & 2.295 & 0.520 & 144 \\
\hline Women's rights & 3.000 & 11.500 & 7.227 & 1.600 & 139 \\
\hline Women's rights gap & 0.304 & 3.833 & 1.193 & 0.421 & 5520 \\
\hline Women's social rights gap & 0.250 & 4.000 & 1.345 & 0.665 & 5889 \\
\hline Women's economic rights gap & 0.400 & 3.500 & 1.213 & 0.412 & 5882 \\
\hline Women's political rights gap & 0.400 & 2.500 & 1.063 & 0.269 & 5588 \\
\hline
\end{tabular}


Table 2. Effects of women's rights gaps on female brain drain ratios using 1990-2000 averages for conditioning variables.

\begin{tabular}{|c|c|c|c|c|c|}
\hline $\begin{array}{l}\text { Estimation Method } \\
\text { Dependent Variable }\end{array}$ & $\begin{array}{c}\text { (I) } \\
\text { OLS } \\
\log (\mathrm{FBR})\end{array}$ & $\begin{array}{c}\text { (II) } \\
\text { OLS } \\
\log (\text { FBR+ } \\
1) \\
\end{array}$ & $\begin{array}{c}\text { (III) } \\
\text { Heckman } \\
\log (\text { FBR })\end{array}$ & $\begin{array}{c}\text { (IV) } \\
\text { PPML } \\
\text { FBR }\end{array}$ & $\begin{array}{c}(\mathrm{V}) \\
\text { PPML } \\
\text { FBR>0 }\end{array}$ \\
\hline Women's Rights Gap & $\begin{array}{l}1.749^{* * * *} \\
(0.191)\end{array}$ & $\begin{array}{l}0.984^{\text {**** }} \\
(0.109)\end{array}$ & $\begin{array}{l}1.748^{* * *} \\
(0.182)\end{array}$ & $\begin{array}{l}1.438^{* * * *} \\
(0.455)\end{array}$ & $\begin{array}{l}1.275^{* * *} \\
(0.428)\end{array}$ \\
\hline (Women's Rights Gap) $^{2}$ & $\begin{array}{c}-0.487^{* * *} \\
(0.061)\end{array}$ & $\begin{array}{c}-0.279^{* * *} \\
(0.037)\end{array}$ & $\begin{array}{c}-0.487^{* * *} \\
(0.059)\end{array}$ & $\begin{array}{c}-0.371^{* * *} \\
(0.179)\end{array}$ & $\begin{array}{l}-0.319^{*} \\
(0.168)\end{array}$ \\
\hline Origin-landlocked dummy & $\begin{array}{l}0.122^{* * * * *} \\
(0.046)\end{array}$ & $\begin{array}{l}0.057^{*} \\
(0.032)\end{array}$ & $\begin{array}{l}0.119^{* * *} \\
(0.049)\end{array}$ & $\begin{array}{c}0.104 \\
(0.074)\end{array}$ & $\begin{array}{c}0.102 \\
(0.070)\end{array}$ \\
\hline Origin Small Island Dummy & $\begin{array}{l}0.221^{* *} \\
(0.090)\end{array}$ & $\begin{array}{l}0.159^{* * * *} \\
(0.062)\end{array}$ & $\begin{array}{l}0.216^{* *} \\
(0.091)\end{array}$ & $\begin{array}{l}0.365^{* *} \\
(0.149)\end{array}$ & $\begin{array}{l}0.345^{* *} \\
(0.147)\end{array}$ \\
\hline Origin-loggdp & $\begin{array}{c}-0.090^{* * *} \\
(0.015)\end{array}$ & $\begin{array}{c}-0.035^{* * *} \\
(0.009)\end{array}$ & $\begin{array}{c}-0.090^{* * *} \\
(0.014)\end{array}$ & $\begin{array}{c}-0.106^{* * * *} \\
(0.023)\end{array}$ & $\begin{array}{c}-0.130^{* * * *} \\
(0.022)\end{array}$ \\
\hline Origin-unemployment & $\begin{array}{c}-0.023^{* * *} \\
(0.003)\end{array}$ & $\begin{array}{c}-0.013^{* * *} \\
(0.002)\end{array}$ & $\begin{array}{c}-0.023^{* * *} \\
(0.003)\end{array}$ & $\begin{array}{c}-0.028^{* * * *} \\
(0.005)\end{array}$ & $\begin{array}{c}-0.028^{* * * *} \\
(0.005)\end{array}$ \\
\hline Destination-loggdp & $\begin{array}{c}0.020 \\
(0.017)\end{array}$ & $\begin{array}{l}0.059^{* * * *} \\
(0.010)\end{array}$ & $\begin{array}{c}0.028 \\
(0.023)\end{array}$ & $\begin{array}{c}0.011 \\
(0.029)\end{array}$ & $\begin{array}{c}-0.059^{* *} \\
(0.027)\end{array}$ \\
\hline Destination - unemployment & $\begin{array}{c}0.003 \\
(0.004)\end{array}$ & $\begin{array}{c}0.000 \\
(0.003)\end{array}$ & $\begin{array}{c}0.003 \\
(0.004)\end{array}$ & $\begin{array}{c}-0.014^{* *} \\
(0.007)\end{array}$ & $\begin{array}{c}-0.015^{* *} \\
(0.006)\end{array}$ \\
\hline Contiguity Dummy & $\begin{array}{c}0.019 \\
(0.081)\end{array}$ & $\begin{array}{l}-0.014 \\
(0.051)\end{array}$ & $\begin{array}{c}0.015 \\
(0.084)\end{array}$ & $\begin{array}{l}-0.036 \\
(0.132)\end{array}$ & $\begin{array}{l}-0.017 \\
(0.124)\end{array}$ \\
\hline Common Language Dummy & $\begin{array}{c}-0.188^{* * *} \\
(0.071)\end{array}$ & $\begin{array}{l}-0.115^{* * *} \\
(0.052)\end{array}$ & $\begin{array}{l}-0.184^{* * *} \\
(0.091)\end{array}$ & $\begin{array}{l}-0.256^{* *} \\
(0.107)\end{array}$ & $\begin{array}{c}-0.251^{* *} \\
(0.110)\end{array}$ \\
\hline Common Second Language Dummy & $\begin{array}{l}0.217^{* * * *} \\
(0.069)\end{array}$ & $\begin{array}{l}0.192^{* * * *} \\
(0.051)\end{array}$ & $\begin{array}{l}0.221^{* *} \\
(0.089)\end{array}$ & $\begin{array}{l}0.295^{* * *} \\
(0.104)\end{array}$ & $\begin{array}{l}0.196^{*} \\
(0.107)\end{array}$ \\
\hline Colony Dummy & $\begin{array}{l}-0.041 \\
(0.070)\end{array}$ & $\begin{array}{l}-0.012 \\
(0.044)\end{array}$ & $\begin{array}{l}-0.039 \\
(0.083)\end{array}$ & $\begin{array}{l}-0.009 \\
(0.129)\end{array}$ & $\begin{array}{l}-0.019 \\
(0.127)\end{array}$ \\
\hline Log distance & $\begin{array}{l}0.005 \\
(0.019)\end{array}$ & $\begin{array}{l}-0.017 \\
(0.012)\end{array}$ & $\begin{array}{c}0.002 \\
(0.020)\end{array}$ & $\begin{array}{c}0.004 \\
(0.031)\end{array}$ & $\begin{array}{c}0.034 \\
(0.030)\end{array}$ \\
\hline Origin government instability & $\begin{array}{c}0.199 \\
(0.445)\end{array}$ & $\begin{array}{c}-0.773^{\text {*** }} \\
(0.328)\end{array}$ & $\begin{array}{c}0.127 \\
(0.493)\end{array}$ & $\begin{array}{l}-1.103^{*} \\
(0.670)\end{array}$ & $\begin{array}{c}-0.263 \\
(0.620)\end{array}$ \\
\hline Mills Test & & & $\begin{array}{l}1.516^{* *} \\
(0.621)\end{array}$ & & \\
\hline Constant & $\begin{array}{l}-0.295 \\
(0.332) \\
\end{array}$ & $\begin{array}{c}0.337 \\
(0.211) \\
\end{array}$ & $\begin{array}{c}-0.345 \\
(0.341) \\
\end{array}$ & $\begin{array}{c}0.853 \\
(0.576) \\
\end{array}$ & $\begin{array}{c}1.462^{* * *} \\
(0.543) \\
\end{array}$ \\
\hline $\begin{array}{l}\text { Observations } \\
\text { F-stat }\end{array}$ & $\begin{array}{c}2617 \\
27.547\end{array}$ & $\begin{array}{c}2970 \\
24.069\end{array}$ & 3713 & 2970 & 2617 \\
\hline $\mathrm{R}^{2}$ & 0.132 & 0.096 & & 0.048 & 0.063 \\
\hline
\end{tabular}

Note: Standard errors in parentheses. ${ }^{*} p<0.10,{ }^{* *} p<0.05,{ }^{* * *} p<.01$

Women's rights gap here is defined as ratio of women's rights levels in destination to women's rights levels in origin. 
Table 3. Effects of women's rights gaps on female brain drain ratios using 1990 values for conditioning variables.

\begin{tabular}{|c|c|c|c|c|c|}
\hline $\begin{array}{l}\text { Estimation Method } \\
\text { Dependent Variable }\end{array}$ & $\begin{array}{c}\text { (I) } \\
\text { OLS } \\
\log (\mathrm{FBR})\end{array}$ & $\begin{array}{c}\text { (II) } \\
\text { OLS } \\
\log (\mathrm{FBR}+ \\
1)\end{array}$ & $\begin{array}{c}\text { (III) } \\
\text { Heckman } \\
\log (\mathrm{FBR})\end{array}$ & $\begin{array}{c}\text { (IV) } \\
\text { PPML } \\
\text { FBR }\end{array}$ & $\begin{array}{c}(\mathrm{V}) \\
\text { PPML } \\
\text { FBR }>0\end{array}$ \\
\hline Women's Rights Gap & $\begin{array}{l}1.398^{* * * *} \\
(0.153)\end{array}$ & $\begin{array}{c}0.764^{* * * *} \\
(0.088)\end{array}$ & $\begin{array}{l}1.399^{* * * *} \\
(0.145)\end{array}$ & $\begin{array}{l}1.186^{* * * *} \\
(0.364)\end{array}$ & $\begin{array}{l}1.109^{* * * *} \\
(0.346)\end{array}$ \\
\hline (Women's Rights Gap) $^{2}$ & $\begin{array}{c}-0.359^{* * *} \\
(0.046)\end{array}$ & $\begin{array}{l}-0.200^{* * * *} \\
(0.027)\end{array}$ & $\begin{array}{l}-0.360^{* * *} \\
(0.044)\end{array}$ & $\begin{array}{l}-0.285^{* *} \\
(0.139)\end{array}$ & $\begin{array}{l}-0.260^{* *} \\
(0.130)\end{array}$ \\
\hline Origin-landlocked dummy & $\begin{array}{l}0.120^{* * *} \\
(0.045)\end{array}$ & $\begin{array}{l}0.056^{*} \\
(0.032)\end{array}$ & $\begin{array}{l}0.116^{* *} \\
(0.048)\end{array}$ & $\begin{array}{c}0.098 \\
(0.070)\end{array}$ & $\begin{array}{c}0.099 \\
(0.066)\end{array}$ \\
\hline Origin Small Island Dummy & $\begin{array}{l}0.201^{* *} \\
(0.090)\end{array}$ & $\begin{array}{l}0.156^{* *} \\
(0.061)\end{array}$ & $\begin{array}{l}0.195^{* *} \\
(0.091)\end{array}$ & $\begin{array}{l}0.340^{* *} \\
(0.147)\end{array}$ & $\begin{array}{l}0.307^{* *} \\
(0.145)\end{array}$ \\
\hline Origin-loggdp & $\begin{array}{l}-0.091^{* * *} \\
(0.015)\end{array}$ & $\begin{array}{l}-0.037^{* * *} \\
(0.009)\end{array}$ & $\begin{array}{c}-0.090^{* * *} \\
(0.014)\end{array}$ & $\begin{array}{c}-0.109^{* * *} \\
(0.021)\end{array}$ & $\begin{array}{c}-0.128^{* * *} \\
(0.020)\end{array}$ \\
\hline Origin-unemployment & $\begin{array}{l}-0.022^{* * *} \\
(0.003)\end{array}$ & $\begin{array}{l}-0.012^{* * *} \\
(0.002)\end{array}$ & $\begin{array}{c}-0.022^{* * *} \\
(0.003)\end{array}$ & $\begin{array}{c}-0.026^{* * *} \\
(0.005)\end{array}$ & $\begin{array}{c}-0.025^{* * *} \\
(0.004)\end{array}$ \\
\hline Destination-loggdp & $\begin{array}{c}0.020 \\
(0.016)\end{array}$ & $\begin{array}{l}0.057^{* * *} \\
(0.010)\end{array}$ & $\begin{array}{c}0.028 \\
(0.022)\end{array}$ & $\begin{array}{c}0.008 \\
(0.027)\end{array}$ & $\begin{array}{l}-0.058^{* *} \\
(0.025)\end{array}$ \\
\hline Destination - unemployment & $\begin{array}{c}0.001 \\
(0.004)\end{array}$ & $\begin{array}{l}-0.001 \\
(0.003)\end{array}$ & $\begin{array}{c}0.001 \\
(0.004)\end{array}$ & $\begin{array}{l}-0.016^{* *} \\
(0.006)\end{array}$ & $\begin{array}{c}-0.017^{* * *} \\
(0.006)\end{array}$ \\
\hline Contiguity Dummy & $\begin{array}{c}0.006 \\
(0.081)\end{array}$ & $\begin{array}{l}-0.024 \\
(0.052)\end{array}$ & $\begin{array}{c}0.001 \\
(0.083)\end{array}$ & $\begin{array}{l}-0.055 \\
(0.129)\end{array}$ & $\begin{array}{c}-0.031 \\
(0.122)\end{array}$ \\
\hline Common Language Dummy & $\begin{array}{c}-0.193^{* * *} \\
(0.071)\end{array}$ & $\begin{array}{c}-0.121^{* *} \\
(0.053)\end{array}$ & $\begin{array}{c}-0.189^{* *} \\
(0.091)\end{array}$ & $\begin{array}{c}-0.267^{* *} \\
(0.106)\end{array}$ & $\begin{array}{c}-0.258^{* *} \\
(0.109)\end{array}$ \\
\hline Common Second Language Dummy & $\begin{array}{l}0.205^{* * *} \\
(0.069)\end{array}$ & $\begin{array}{l}0.193^{* * *} \\
(0.052)\end{array}$ & $\begin{array}{l}0.211^{* *} \\
(0.089)\end{array}$ & $\begin{array}{l}0.285^{* * *} \\
(0.103)\end{array}$ & $\begin{array}{c}0.179^{*} \\
(0.106)\end{array}$ \\
\hline Colony Dummy & $\begin{array}{c}-0.032 \\
(0.070)\end{array}$ & $\begin{array}{l}-0.009 \\
(0.044)\end{array}$ & $\begin{array}{c}-0.029 \\
(0.082)\end{array}$ & $\begin{array}{c}0.007 \\
(0.126)\end{array}$ & $\begin{array}{c}-0.003 \\
(0.124)\end{array}$ \\
\hline Log distance & $\begin{array}{c}0.002 \\
(0.019)\end{array}$ & $\begin{array}{l}-0.018 \\
(0.012)\end{array}$ & $\begin{array}{l}-0.001 \\
(0.020)\end{array}$ & $\begin{array}{l}-0.000 \\
(0.031)\end{array}$ & $\begin{array}{c}0.029 \\
(0.030)\end{array}$ \\
\hline Origin government instability & $\begin{array}{c}0.599 \\
(0.429)\end{array}$ & $\begin{array}{l}-0.618^{*} \\
(0.321)\end{array}$ & $\begin{array}{c}0.518 \\
(0.475)\end{array}$ & $\begin{array}{l}-0.729 \\
(0.615)\end{array}$ & $\begin{array}{c}0.188 \\
(0.562)\end{array}$ \\
\hline Mills Test & & & $\begin{array}{l}1.694^{\text {*** }} \\
(0.596)\end{array}$ & & \\
\hline Constant & $\begin{array}{c}-0.137 \\
(0.311)\end{array}$ & $\begin{array}{l}0.501^{* *} \\
(0.200)\end{array}$ & $\begin{array}{l}-0.194 \\
(0.321)\end{array}$ & $\begin{array}{c}1.011^{*} \\
(0.516)\end{array}$ & $\begin{array}{l}1.461^{* * *} \\
(0.480)\end{array}$ \\
\hline Observations & 2644 & 3003 & 3752 & 3003 & 2644 \\
\hline $\begin{array}{l}\text { F-stat } \\
\mathrm{R}^{2}\end{array}$ & $\begin{array}{c}28.378 \\
0.133\end{array}$ & $\begin{array}{c}23.160 \\
0.093\end{array}$ & & 0.048 & 0.066 \\
\hline
\end{tabular}

Standard errors in parentheses

${ }^{*} p<0.10,{ }^{* *} p<0.05,{ }^{* * *} p<.01$ 
Table 4. Effects of women's economic rights gaps on female brain drain ratios using 1990-2000 averages for conditioning variables.

\begin{tabular}{|c|c|c|c|c|c|}
\hline $\begin{array}{l}\text { Estimation Method } \\
\text { Dependent Variable }\end{array}$ & $\begin{array}{c}\text { (I) } \\
\text { OLS } \\
\log (\mathrm{FBR})\end{array}$ & $\begin{array}{c}\text { (II) } \\
\text { OLS } \\
\log (\text { FBR+ } \\
1)\end{array}$ & $\begin{array}{c}\text { (III) } \\
\text { Heckman } \\
\text { Log(FBR) }\end{array}$ & $\begin{array}{l}\text { (IV) } \\
\text { PPML } \\
\text { FBR }\end{array}$ & $\begin{array}{c}(\mathrm{V}) \\
\text { PPML } \\
\text { FBR }>0\end{array}$ \\
\hline Women's economic Rights Gap & $\begin{array}{l}1.422^{* * *} \\
(0.219)\end{array}$ & $\begin{array}{l}0.762^{* * * *} \\
(0.132)\end{array}$ & $\begin{array}{l}1.424^{* * * *} \\
(0.193)\end{array}$ & $\begin{array}{c}0.444 \\
(0.461)\end{array}$ & $\begin{array}{c}0.230 \\
(0.453)\end{array}$ \\
\hline (Women's economic Rights Gap) $^{2}$ & $\begin{array}{l}-0.342^{* * * *} \\
(0.068)\end{array}$ & $\begin{array}{l}-0.173^{* * *} \\
(0.043)\end{array}$ & $\begin{array}{l}-0.343^{* * * *} \\
(0.061)\end{array}$ & $\begin{array}{l}-0.039 \\
(0.165)\end{array}$ & $\begin{array}{c}0.008 \\
(0.162)\end{array}$ \\
\hline Origin-landlocked dummy & $\begin{array}{l}0.181^{* * *} \\
(0.046)\end{array}$ & $\begin{array}{l}0.091^{* * *} \\
(0.033)\end{array}$ & $\begin{array}{l}0.177^{* * * *} \\
(0.048)\end{array}$ & $\begin{array}{l}0.179^{* *} \\
(0.070)\end{array}$ & $\begin{array}{c}0.177^{* * *} \\
(0.066)\end{array}$ \\
\hline Origin Small Island Dummy & $\begin{array}{l}0.309^{* * * *} \\
(0.091)\end{array}$ & $\begin{array}{l}0.203^{* * * *} \\
(0.062)\end{array}$ & $\begin{array}{l}0.303^{* * * *} \\
(0.092)\end{array}$ & $\begin{array}{l}0.387^{* *} \\
(0.150)\end{array}$ & $\begin{array}{l}0.350^{* *} \\
(0.148)\end{array}$ \\
\hline Origin-loggdp & $\begin{array}{c}-0.080^{* * * *} \\
(0.016)\end{array}$ & $\begin{array}{c}-0.025^{* * *} \\
(0.010)\end{array}$ & $\begin{array}{l}-0.080^{* * * *} \\
(0.015)\end{array}$ & $\begin{array}{l}-0.104^{* * *} \\
(0.022)\end{array}$ & $\begin{array}{c}-0.135^{\text {**** }} \\
(0.021)\end{array}$ \\
\hline Origin-unemployment & $\begin{array}{c}-0.021^{* * * *} \\
(0.003)\end{array}$ & $\begin{array}{c}-0.011^{* * * *} \\
(0.002)\end{array}$ & $\begin{array}{l}-0.021^{* * * *} \\
(0.003)\end{array}$ & $\begin{array}{l}-0.022^{* * *} \\
(0.005)\end{array}$ & $\begin{array}{c}-0.022^{* * * *} \\
(0.005)\end{array}$ \\
\hline Destination-loggdp & $\begin{array}{c}0.004 \\
(0.017)\end{array}$ & $\begin{array}{l}0.049^{* * * *} \\
(0.011)\end{array}$ & $\begin{array}{c}0.013 \\
(0.023)\end{array}$ & $\begin{array}{c}0.017 \\
(0.028)\end{array}$ & $\begin{array}{l}-0.047^{*} \\
(0.026)\end{array}$ \\
\hline Destination - unemployment & $\begin{array}{l}0.013^{* * * *} \\
(0.004)\end{array}$ & $\begin{array}{l}0.006^{* *} \\
(0.002)\end{array}$ & $\begin{array}{l}0.013^{* * * *} \\
(0.004)\end{array}$ & $\begin{array}{l}-0.002 \\
(0.006)\end{array}$ & $\begin{array}{l}-0.004 \\
(0.006)\end{array}$ \\
\hline Contiguity Dummy & $\begin{array}{c}0.013 \\
(0.078)\end{array}$ & $\begin{array}{l}-0.002 \\
(0.049)\end{array}$ & $\begin{array}{c}0.009 \\
(0.082)\end{array}$ & $\begin{array}{l}-0.019 \\
(0.127)\end{array}$ & $\begin{array}{l}-0.013 \\
(0.120)\end{array}$ \\
\hline Common Language Dummy & $\begin{array}{c}-0.221^{* * *} \\
(0.070)\end{array}$ & $\begin{array}{l}-0.131^{* * *} \\
(0.051)\end{array}$ & $\begin{array}{l}-0.216^{* * *} \\
(0.089)\end{array}$ & $\begin{array}{c}-0.326^{* * * *} \\
(0.104)\end{array}$ & $\begin{array}{c}-0.339^{* * *} \\
(0.106)\end{array}$ \\
\hline Common Second Language Dummy & $\begin{array}{l}0.212^{* * * *} \\
(0.068)\end{array}$ & $\begin{array}{l}0.196^{* * * *} \\
(0.050)\end{array}$ & $\begin{array}{l}0.217^{* *} \\
(0.087)\end{array}$ & $\begin{array}{l}0.320^{* * *} \\
(0.100)\end{array}$ & $\begin{array}{l}0.230^{* *} \\
(0.102)\end{array}$ \\
\hline Colony Dummy & $\begin{array}{l}-0.039 \\
(0.067)\end{array}$ & $\begin{array}{l}-0.014 \\
(0.042)\end{array}$ & $\begin{array}{l}-0.037 \\
(0.082)\end{array}$ & $\begin{array}{l}-0.024 \\
(0.126)\end{array}$ & $\begin{array}{l}-0.036 \\
(0.124)\end{array}$ \\
\hline Log distance & $\begin{array}{c}0.003 \\
(0.019)\end{array}$ & $\begin{array}{l}-0.015 \\
(0.011)\end{array}$ & $\begin{array}{c}0.000 \\
(0.019)\end{array}$ & $\begin{array}{c}0.018 \\
(0.031)\end{array}$ & $\begin{array}{c}0.049 \\
(0.030)\end{array}$ \\
\hline Origin government instability & $\begin{array}{c}0.480 \\
(0.460)\end{array}$ & $\begin{array}{l}-0.451 \\
(0.328)\end{array}$ & $\begin{array}{c}0.406 \\
(0.471)\end{array}$ & $\begin{array}{l}-0.162 \\
(0.660)\end{array}$ & $\begin{array}{c}0.583 \\
(0.617)\end{array}$ \\
\hline Mills Test & & & $\begin{array}{l}1.732^{* * * *} \\
(0.574)\end{array}$ & & \\
\hline Constant & $\begin{array}{l}-0.238 \\
(0.329)\end{array}$ & $\begin{array}{c}0.278 \\
(0.210)\end{array}$ & $\begin{array}{l}-0.305 \\
(0.341)\end{array}$ & $\begin{array}{l}0.944^{*} \\
(0.529)\end{array}$ & $\begin{array}{c}1.668^{* * *} \\
(0.502)\end{array}$ \\
\hline $\begin{array}{l}\text { Observations } \\
\text { F-stat }\end{array}$ & $\begin{array}{c}2772 \\
26.016\end{array}$ & $\begin{array}{c}3165 \\
20.260\end{array}$ & 4005 & 3165 & 2772 \\
\hline $\mathrm{R}^{2}$ & 0.118 & 0.084 & & 0.039 & 0.056 \\
\hline
\end{tabular}

Standard errors in parentheses

${ }^{*} p<0.10,{ }^{* *} p<0.05,{ }^{* * *} p<.01$ 
Table 5. Effects of women's political rights gaps on female brain drain ratios using 1990-2000 averages for conditioning variables.

\begin{tabular}{|c|c|c|c|c|c|}
\hline $\begin{array}{l}\text { Estimation Method } \\
\text { Dependent Variable }\end{array}$ & $\begin{array}{c}\text { (I) } \\
\text { OLS } \\
\log (\mathrm{FBR})\end{array}$ & $\begin{array}{c}\text { (II) } \\
\text { OLS } \\
\log (F B R+ \\
1)\end{array}$ & $\begin{array}{c}\text { (III) } \\
\text { Heckman } \\
\text { Log(FBR) }\end{array}$ & $\begin{array}{c}\text { (IV) } \\
\text { PPML } \\
\text { FBR }\end{array}$ & $\begin{array}{c}(\mathrm{V}) \\
\text { PPML } \\
\text { FBR }>0\end{array}$ \\
\hline Women's Political Rights Gap & $\begin{array}{l}1.058^{* * * *} \\
(0.127)\end{array}$ & $\begin{array}{l}0.617^{* * *} \\
(0.073)\end{array}$ & $\begin{array}{l}1.068^{* * * *} \\
(0.125)\end{array}$ & $\begin{array}{l}1.299^{* * * *} \\
(0.187)\end{array}$ & $\begin{array}{l}1.208^{* * * *} \\
(0.182)\end{array}$ \\
\hline (Women's Political Rights Gap) $^{2}$ & $\begin{array}{c}-0.273^{* * *} \\
(0.033)\end{array}$ & $\begin{array}{c}-0.167^{* * * *} \\
(0.020)\end{array}$ & $\begin{array}{c}-0.276^{* * *} \\
(0.036)\end{array}$ & $\begin{array}{c}-0.365^{* * *} \\
(0.050)\end{array}$ & $\begin{array}{c}-0.330^{* * * *} \\
(0.047)\end{array}$ \\
\hline Origin-landlocked dummy & $\begin{array}{l}0.146^{* * * *} \\
(0.046)\end{array}$ & $\begin{array}{l}0.075^{* *} \\
(0.033)\end{array}$ & $\begin{array}{l}0.141^{* * * *} \\
(0.049)\end{array}$ & $\begin{array}{l}0.145^{* *} \\
(0.071)\end{array}$ & $\begin{array}{l}0.143^{* * *} \\
(0.067)\end{array}$ \\
\hline Origin Small Island Dummy & $\begin{array}{l}0.167^{*} \\
(0.091)\end{array}$ & $\begin{array}{l}0.123^{* *} \\
(0.062)\end{array}$ & $\begin{array}{l}0.160^{*} \\
(0.092)\end{array}$ & $\begin{array}{l}0.258^{*} \\
(0.151)\end{array}$ & $\begin{array}{c}0.240 \\
(0.149)\end{array}$ \\
\hline Origin-loggdp & $\begin{array}{l}-0.120^{* * * *} \\
(0.014)\end{array}$ & $\begin{array}{c}-0.050^{* * * *} \\
(0.009)\end{array}$ & $\begin{array}{c}-0.119^{* * *} \\
(0.014)\end{array}$ & $\begin{array}{c}-0.115^{* * *} \\
(0.022)\end{array}$ & $\begin{array}{c}-0.136^{* * * *} \\
(0.022)\end{array}$ \\
\hline Origin-unemployment & $\begin{array}{c}-0.022^{* * * *} \\
(0.003)\end{array}$ & $\begin{array}{c}-0.013^{* * *} \\
(0.002)\end{array}$ & $\begin{array}{c}-0.023^{* * * *} \\
(0.003)\end{array}$ & $\begin{array}{c}-0.026^{* * *} \\
(0.005)\end{array}$ & $\begin{array}{c}-0.025^{* * *} \\
(0.005)\end{array}$ \\
\hline Destination-loggdp & $\begin{array}{l}0.061^{* * * *} \\
(0.015)\end{array}$ & $\begin{array}{l}0.080^{* * * * *} \\
(0.010)\end{array}$ & $\begin{array}{l}0.071^{* * * *} \\
(0.021)\end{array}$ & $\begin{array}{l}0.041 \\
(0.027)\end{array}$ & $\begin{array}{l}-0.030 \\
(0.026)\end{array}$ \\
\hline Destination - unemployment & $\begin{array}{c}0.002 \\
(0.004)\end{array}$ & $\begin{array}{l}-0.000 \\
(0.003)\end{array}$ & $\begin{array}{c}0.002 \\
(0.004)\end{array}$ & $\begin{array}{l}-0.015^{* *} \\
(0.007)\end{array}$ & $\begin{array}{l}-0.0166^{* *} \\
(0.007)\end{array}$ \\
\hline Contiguity Dummy & $\begin{array}{c}0.028 \\
(0.082)\end{array}$ & $\begin{array}{l}-0.008 \\
(0.052)\end{array}$ & $\begin{array}{c}0.022 \\
(0.084)\end{array}$ & $\begin{array}{l}-0.040 \\
(0.130)\end{array}$ & $\begin{array}{l}-0.021 \\
(0.123)\end{array}$ \\
\hline Common Language Dummy & $\begin{array}{c}-0.222^{* * * *} \\
(0.073)\end{array}$ & $\begin{array}{c}-0.145^{* * *} \\
(0.053)\end{array}$ & $\begin{array}{l}-0.218^{* * *} \\
(0.092)\end{array}$ & $\begin{array}{c}-0.342^{* * *} \\
(0.107)\end{array}$ & $\begin{array}{c}-0.327^{* * *} \\
(0.111)\end{array}$ \\
\hline Common Second Language Dummy & $\begin{array}{l}0.243^{* * * *} \\
(0.070)\end{array}$ & $\begin{array}{l}0.215^{* * *} \\
(0.052)\end{array}$ & $\begin{array}{l}0.249^{* * * *} \\
(0.090)\end{array}$ & $\begin{array}{c}0.346^{* * *} \\
(0.103)\end{array}$ & $\begin{array}{l}0.238^{* *} \\
(0.106)\end{array}$ \\
\hline Colony Dummy & $\begin{array}{l}-0.044 \\
(0.070)\end{array}$ & $\begin{array}{l}-0.015 \\
(0.044)\end{array}$ & $\begin{array}{l}-0.040 \\
(0.083)\end{array}$ & $\begin{array}{l}-0.015 \\
(0.127)\end{array}$ & $\begin{array}{l}-0.027 \\
(0.126)\end{array}$ \\
\hline Log distance & $\begin{array}{c}0.016 \\
(0.019)\end{array}$ & $\begin{array}{l}-0.011 \\
(0.012)\end{array}$ & $\begin{array}{c}0.012 \\
(0.020)\end{array}$ & $\begin{array}{l}0.021 \\
(0.031)\end{array}$ & $\begin{array}{l}0.052^{*} \\
(0.029)\end{array}$ \\
\hline Origin government instability & $\begin{array}{l}0.778^{*} \\
(0.463)\end{array}$ & $\begin{array}{l}-0.364 \\
(0.345)\end{array}$ & $\begin{array}{c}0.685 \\
(0.488)\end{array}$ & $\begin{array}{c}0.040 \\
(0.664)\end{array}$ & $\begin{array}{c}0.815 \\
(0.622)\end{array}$ \\
\hline Mills Test & & & $\begin{array}{c}2.101^{\text {********** }} \\
(0.613)\end{array}$ & & \\
\hline Constant & $\begin{array}{c}-0.143 \\
(0.325)\end{array}$ & $\begin{array}{c}0.408^{*} \\
(0.209)\end{array}$ & $\begin{array}{l}-0.215 \\
(0.334)\end{array}$ & $\begin{array}{c}0.433 \\
(0.467)\end{array}$ & $\begin{array}{l}0.976^{* *} \\
(0.446)\end{array}$ \\
\hline Observations & 2647 & 3003 & 3763 & 3003 & 2647 \\
\hline $\begin{array}{l}\text { F-stat } \\
\mathrm{R}^{2}\end{array}$ & $\begin{array}{c}27.000 \\
0.127\end{array}$ & $\begin{array}{c}21.752 \\
0.089\end{array}$ & & 0.048 & 0.067 \\
\hline
\end{tabular}

Standard errors in parentheses

${ }^{*} p<0.10,{ }^{* *} p<0.05,{ }^{* * *} p<.01$ 
Table 6. Effects of women's social rights gaps on female brain drain ratios using 1990-2000 averages for conditioning variables.

\begin{tabular}{|c|c|c|c|c|c|}
\hline $\begin{array}{l}\text { Estimation Method } \\
\text { Dependent Variable }\end{array}$ & $\begin{array}{c}\text { (I) } \\
\text { OLS } \\
\log (\mathrm{FBR})\end{array}$ & $\begin{array}{c}\text { (II) } \\
\text { OLS } \\
\log (\mathrm{FBR}+1)\end{array}$ & $\begin{array}{c}\text { (III) } \\
\text { Heckman } \\
\text { Log(FBR) }\end{array}$ & $\begin{array}{c}\text { (IV) } \\
\text { PPML } \\
\text { FBR }\end{array}$ & $\begin{array}{c}(\mathrm{V}) \\
\text { PPML } \\
\text { FBR }>0\end{array}$ \\
\hline Women's Social Rights Gap & $\begin{array}{l}0.811^{\text {**** }} \\
(0.097)\end{array}$ & $\begin{array}{l}0.426^{* * *} \\
(0.058)\end{array}$ & $\begin{array}{l}0.804^{* * * *} \\
(0.095)\end{array}$ & $\begin{array}{c}0.677^{* * * *} \\
(0.154)\end{array}$ & $\begin{array}{c}0.661^{* * *} \\
(0.146)\end{array}$ \\
\hline (Women's Social Rights Gap) $^{2}$ & $\begin{array}{c}-0.168^{* * *} \\
(0.023)\end{array}$ & $\begin{array}{c}-0.090^{* * *} \\
(0.014)\end{array}$ & $\begin{array}{c}-0.166^{* * * *} \\
(0.023)\end{array}$ & $\begin{array}{c}-0.126^{* * *} \\
(0.049)\end{array}$ & $\begin{array}{c}-0.120^{* * * *} \\
(0.046)\end{array}$ \\
\hline Origin-landlocked dummy & $\begin{array}{l}0.166^{* * * *} \\
(0.045)\end{array}$ & $\begin{array}{l}0.077^{* * *} \\
(0.032)\end{array}$ & $\begin{array}{l}0.162^{* * * *} \\
(0.048)\end{array}$ & $\begin{array}{l}0.136^{* *} \\
(0.069)\end{array}$ & $\begin{array}{l}0.142^{* *} \\
(0.065)\end{array}$ \\
\hline Origin Small Island Dummy & $\begin{array}{l}0.229^{* *} \\
(0.090)\end{array}$ & $\begin{array}{l}0.159^{* * * *} \\
(0.062)\end{array}$ & $\begin{array}{l}0.224^{* * *} \\
(0.091)\end{array}$ & $\begin{array}{l}0.367^{* *} \\
(0.149)\end{array}$ & $\begin{array}{l}0.349^{* *} \\
(0.146)\end{array}$ \\
\hline Origin-loggdp & $\begin{array}{l}-0.091^{* * *} \\
(0.015)\end{array}$ & $\begin{array}{l}-0.035^{* * *} \\
(0.009)\end{array}$ & $\begin{array}{c}-0.091^{* * *} \\
(0.014)\end{array}$ & $\begin{array}{l}-0.100^{* * *} \\
(0.022)\end{array}$ & $\begin{array}{c}-0.122^{* * * *} \\
(0.021)\end{array}$ \\
\hline Origin-unemployment & $\begin{array}{c}-0.021^{* * *} \\
(0.003)\end{array}$ & $\begin{array}{c}-0.011^{* * *} \\
(0.002)\end{array}$ & $\begin{array}{c}-0.021^{* * * *} \\
(0.003)\end{array}$ & $\begin{array}{c}-0.024^{* * *} \\
(0.005)\end{array}$ & $\begin{array}{c}-0.025^{* * * *} \\
(0.004)\end{array}$ \\
\hline Destination-loggdp & $\begin{array}{c}0.013 \\
(0.017)\end{array}$ & $\begin{array}{l}0.059^{* * * *} \\
(0.010)\end{array}$ & $\begin{array}{c}0.020 \\
(0.024)\end{array}$ & $\begin{array}{c}0.005 \\
(0.028)\end{array}$ & $\begin{array}{c}-0.071^{* * * *} \\
(0.026)\end{array}$ \\
\hline Destination - unemployment & $\begin{array}{l}0.006 \\
(0.004)\end{array}$ & $\begin{array}{c}0.001 \\
(0.003)\end{array}$ & $\begin{array}{c}0.006 \\
(0.004)\end{array}$ & $\begin{array}{l}-0.012^{*} \\
(0.006)\end{array}$ & $\begin{array}{c}-0.013^{* *} \\
(0.006)\end{array}$ \\
\hline Contiguity Dummy & $\begin{array}{c}0.004 \\
(0.079)\end{array}$ & $\begin{array}{c}0.004 \\
(0.050)\end{array}$ & $\begin{array}{c}0.001 \\
(0.081)\end{array}$ & $\begin{array}{l}-0.023 \\
(0.125)\end{array}$ & $\begin{array}{l}-0.038 \\
(0.118)\end{array}$ \\
\hline Common Language Dummy & $\begin{array}{c}-0.203^{* * * *} \\
(0.069)\end{array}$ & $\begin{array}{l}-0.112^{* *} \\
(0.050)\end{array}$ & $\begin{array}{l}-0.199^{* *} \\
(0.088)\end{array}$ & $\begin{array}{c}-0.288^{* * * *} \\
(0.101)\end{array}$ & $\begin{array}{c}-0.305^{* * * *} \\
(0.102)\end{array}$ \\
\hline Common Second Language Dummy & $\begin{array}{l}0.230^{* * * * *} \\
(0.067)\end{array}$ & $\begin{array}{l}0.198^{* * * *} \\
(0.049)\end{array}$ & $\begin{array}{l}0.234^{* * * *} \\
(0.086)\end{array}$ & $\begin{array}{c}0.331^{* * *} \\
(0.099)\end{array}$ & $\begin{array}{l}0.241^{* *} \\
(0.099)\end{array}$ \\
\hline Colony Dummy & $\begin{array}{l}-0.050 \\
(0.068)\end{array}$ & $\begin{array}{l}-0.019 \\
(0.042)\end{array}$ & $\begin{array}{l}-0.048 \\
(0.081)\end{array}$ & $\begin{array}{l}-0.036 \\
(0.123)\end{array}$ & $\begin{array}{l}-0.048 \\
(0.122)\end{array}$ \\
\hline Log distance & $\begin{array}{l}-0.002 \\
(0.019)\end{array}$ & $\begin{array}{l}-0.017 \\
(0.011)\end{array}$ & $\begin{array}{l}-0.005 \\
(0.019)\end{array}$ & $\begin{array}{l}-0.003 \\
(0.031)\end{array}$ & $\begin{array}{c}0.023 \\
(0.029)\end{array}$ \\
\hline Origin government instability & $\begin{array}{c}0.072 \\
(0.438)\end{array}$ & $\begin{array}{l}-0.696^{* *} \\
(0.320)\end{array}$ & $\begin{array}{c}0.010 \\
(0.472)\end{array}$ & $\begin{array}{l}-0.932 \\
(0.662)\end{array}$ & $\begin{array}{l}-0.222 \\
(0.608)\end{array}$ \\
\hline Mills Test & & & $\begin{array}{l}1.287^{* * *} \\
(0.569)\end{array}$ & & \\
\hline Constant & $\begin{array}{c}0.424 \\
(0.311) \\
\end{array}$ & $\begin{array}{l}0.653^{* * * *} \\
(0.204)\end{array}$ & $\begin{array}{c}0.373 \\
(0.323) \\
\end{array}$ & $\begin{array}{l}1.319^{* * *} \\
(0.507)\end{array}$ & $\begin{array}{c}1.940^{* * *} \\
(0.478) \\
\end{array}$ \\
\hline Observations & 2779 & 3172 & 4006 & 3172 & 2779 \\
\hline $\begin{array}{l}\text { F-stat } \\
\mathrm{R}^{2}\end{array}$ & $\begin{array}{c}27.341 \\
0.119\end{array}$ & $\begin{array}{c}21.082 \\
0.082\end{array}$ & & 0.044 & 0.063 \\
\hline
\end{tabular}

Standard errors in parentheses

${ }^{*} p<0.10,{ }^{* * *} p<0.05,{ }^{* * * *} p<.01$ 
Table 7. Effects of women's political, economic, and social rights gaps on female brain drain ratios using 19902000 averages for conditioning variables.

\begin{tabular}{|c|c|c|c|c|c|}
\hline $\begin{array}{l}\text { Estimation Method } \\
\text { Dependent Variable }\end{array}$ & $\begin{array}{c}\text { (I) } \\
\text { OLS } \\
\log (\text { FBR })\end{array}$ & $\begin{array}{c}\text { (II) } \\
\text { OLS } \\
\log (\mathrm{FBR}+1)\end{array}$ & $\begin{array}{c}\text { (III) } \\
\text { Heckman } \\
\text { Log(FBR) }\end{array}$ & $\begin{array}{l}\text { (IV) } \\
\text { PPML } \\
\text { FBR }\end{array}$ & $\begin{array}{c}\text { (V) } \\
\text { PPML } \\
\text { FBR }>0\end{array}$ \\
\hline Women's Political Rights Gap & $0.571^{* * * *}$ & $0.341^{* * * *}$ & $0.579^{* * * *}$ & $0.798^{* * * *}$ & $0.715^{* * * *}$ \\
\hline (Women's Political Rights Gap) $^{2}$ & $\begin{array}{c}-0.178^{* * * *} \\
(0.037)\end{array}$ & $\begin{array}{c}-0.113^{* * * *} \\
(0.023)\end{array}$ & $\begin{array}{c}-0.181^{* * * *} \\
(0.039)\end{array}$ & $\begin{array}{c}-0.276^{* * * *} \\
(0.065)\end{array}$ & $\begin{array}{c}-0.242^{* * * *} \\
(0.061)\end{array}$ \\
\hline Women's Economic Rights Gap & $\begin{array}{l}1.177^{* * * *} \\
(0.260)\end{array}$ & $\begin{array}{c}0.789^{* * *} \\
(0.156)\end{array}$ & $\begin{array}{l}1.176^{* * *} \\
(0.247)\end{array}$ & $\begin{array}{c}0.292 \\
(0.534)\end{array}$ & $\begin{array}{l}-0.133 \\
(0.528)\end{array}$ \\
\hline (Women's Economic Rights Gap) $^{2}$ & $\begin{array}{c}-0.268^{* * * *} \\
(0.076)\end{array}$ & $\begin{array}{c}-0.161^{* * * *} \\
(0.047)\end{array}$ & $\begin{array}{c}-0.268^{* * *} \\
(0.072)\end{array}$ & $\begin{array}{c}0.003 \\
(0.180)\end{array}$ & $\begin{array}{c}0.085 \\
(0.177)\end{array}$ \\
\hline Women's Social Rights Gap & $\begin{array}{c}0.172 \\
(0.131)\end{array}$ & $\begin{array}{c}0.011 \\
(0.082)\end{array}$ & $\begin{array}{c}0.172 \\
(0.135)\end{array}$ & $\begin{array}{c}0.269 \\
(0.211)\end{array}$ & $\begin{array}{l}0.427^{* *} \\
(0.204)\end{array}$ \\
\hline (Women's Social Rights Gap) $^{2}$ & $\begin{array}{l}-0.042 \\
(0.029)\end{array}$ & $\begin{array}{c}-0.012 \\
(0.018)\end{array}$ & $\begin{array}{c}-0.042 \\
(0.030)\end{array}$ & $\begin{array}{l}-0.048 \\
(0.053)\end{array}$ & $\begin{array}{l}-0.071 \\
(0.052)\end{array}$ \\
\hline Origin-landlocked dummy & $\begin{array}{l}0.114^{* *} \\
(0.046)\end{array}$ & $\begin{array}{c}0.047 \\
(0.032)\end{array}$ & $\begin{array}{l}0.108^{* *} \\
(0.050)\end{array}$ & $\begin{array}{c}0.095 \\
(0.074)\end{array}$ & $\begin{array}{c}0.105 \\
(0.070)\end{array}$ \\
\hline Origin small island dummy & $\begin{array}{c}0.255^{* * * *} \\
(0.092)\end{array}$ & $\begin{array}{c}0.187^{* * * * *} \\
(0.063)\end{array}$ & $\begin{array}{c}0.250^{* * * *} \\
(0.092)\end{array}$ & $\begin{array}{l}0.367^{* *} \\
(0.152)\end{array}$ & $\begin{array}{l}0.322^{* * *} \\
(0.148)\end{array}$ \\
\hline Origin-loggdp & $\begin{array}{c}-0.068^{* * * *} \\
(0.017)\end{array}$ & $\begin{array}{l}-0.018^{*} \\
(0.010)\end{array}$ & $\begin{array}{c}-0.068^{* * *} \\
(0.016)\end{array}$ & $\begin{array}{c}-0.083^{* * *} \\
(0.024)\end{array}$ & $\begin{array}{c}-0.112^{* * *} \\
(0.023)\end{array}$ \\
\hline Origin-unemployment & $\begin{array}{c}-0.025^{* * * *} \\
(0.003)\end{array}$ & $\begin{array}{c}-0.014^{* * * *} \\
(0.002)\end{array}$ & $\begin{array}{c}-0.025^{* * *} \\
(0.003)\end{array}$ & $\begin{array}{c}-0.030^{* * *} \\
(0.005)\end{array}$ & $\begin{array}{c}-0.029^{* * * *} \\
(0.005)\end{array}$ \\
\hline Destination-loggdp & $\begin{array}{c}0.006 \\
(0.018)\end{array}$ & $\begin{array}{c}0.048^{* * * * *} \\
(0.011)\end{array}$ & $\begin{array}{c}0.015 \\
(0.024)\end{array}$ & $\begin{array}{c}0.004 \\
(0.029)\end{array}$ & $\begin{array}{c}-0.062^{* *} \\
(0.027)\end{array}$ \\
\hline Destination - unemployment & $\begin{array}{c}0.006 \\
(0.004)\end{array}$ & $\begin{array}{c}0.003 \\
(0.003)\end{array}$ & $\begin{array}{c}0.006 \\
(0.004)\end{array}$ & $\begin{array}{l}-0.014^{*} \\
(0.007)\end{array}$ & $\begin{array}{c}-0.017^{* * *} \\
(0.007)\end{array}$ \\
\hline Contiguity dummy & $\begin{array}{c}0.018 \\
(0.080)\end{array}$ & $\begin{array}{l}-0.019 \\
(0.051)\end{array}$ & $\begin{array}{c}0.013 \\
(0.084)\end{array}$ & $\begin{array}{l}-0.042 \\
(0.132)\end{array}$ & $\begin{array}{l}-0.016 \\
(0.124)\end{array}$ \\
\hline Common first language dummy & $\begin{array}{c}-0.198^{* * * *} \\
(0.071)\end{array}$ & $\begin{array}{l}-0.121^{* * *} \\
(0.052)\end{array}$ & $\begin{array}{l}-0.194^{* * *} \\
(0.091)\end{array}$ & $\begin{array}{c}-0.298^{* * *} \\
(0.109)\end{array}$ & $\begin{array}{c}-0.296^{* * * *} \\
(0.110)\end{array}$ \\
\hline Common second language dummy & $\begin{array}{c}0.221^{\text {**** }} \\
(0.069)\end{array}$ & $\begin{array}{c}0.191^{* * * * *} \\
(0.051)\end{array}$ & $\begin{array}{l}0.227^{* *} \\
(0.089)\end{array}$ & $\begin{array}{c}0.337^{* * *} \\
(0.105)\end{array}$ & $\begin{array}{l}0.251^{* *} \\
(0.107)\end{array}$ \\
\hline Colony dummy & $\begin{array}{l}-0.032 \\
(0.069)\end{array}$ & $\begin{array}{l}-0.006 \\
(0.043)\end{array}$ & $\begin{array}{l}-0.029 \\
(0.083)\end{array}$ & $\begin{array}{l}-0.005 \\
(0.128)\end{array}$ & $\begin{array}{l}-0.019 \\
(0.127)\end{array}$ \\
\hline Log distance & $\begin{array}{c}0.002 \\
(0.019)\end{array}$ & $\begin{array}{l}-0.019 \\
(0.012)\end{array}$ & $\begin{array}{l}-0.002 \\
(0.020)\end{array}$ & $\begin{array}{c}0.002 \\
(0.032)\end{array}$ & $\begin{array}{c}0.033 \\
(0.031)\end{array}$ \\
\hline Origin government instability & $\begin{array}{c}0.498 \\
(0.456)\end{array}$ & $\begin{array}{l}-0.555^{*} \\
(0.334)\end{array}$ & $\begin{array}{c}0.408 \\
(0.498)\end{array}$ & $\begin{array}{l}-0.805 \\
(0.679)\end{array}$ & $\begin{array}{l}-0.017 \\
(0.626)\end{array}$ \\
\hline Mills Test & & & $\begin{array}{l}1.679^{* * * *} \\
(0.589)\end{array}$ & & \\
\hline Constant & $\begin{array}{l}-0.594^{*} \\
(0.347)\end{array}$ & $\begin{array}{c}0.093 \\
(0.219) \\
\end{array}$ & $\begin{array}{l}-0.660^{*} \\
(0.355)\end{array}$ & $\begin{array}{c}0.717 \\
(0.555)\end{array}$ & $\begin{array}{c}1.497^{* * *} \\
(0.526)\end{array}$ \\
\hline Observations & 2617 & 2970 & 3733 & 2970 & 2617 \\
\hline $\begin{array}{l}\text { F-stat } \\
\mathrm{R}^{2}\end{array}$ & $\begin{array}{c}22.724 \\
0.138\end{array}$ & $\begin{array}{c}20.832 \\
0.107\end{array}$ & & 0.054 & 0.070 \\
\hline
\end{tabular}

$t$ statistics in parentheses

${ }^{*} p<0.10,{ }^{* *} p<0.05,{ }^{* * *} p<.01$ 
Table 8. Categorization of countries into four "nests".

\begin{tabular}{|c|c|c|c|c|c|c|}
\hline Asia and the Middle East & & Latin America & Sub-Saharan Africa & & Western Democracies & and Former Soviet Union \\
\hline Afghanistan & Oman & Argentina & Angola & Mauritania & Albania & Kazakhstan \\
\hline Algeria & Pakistan & Bahamas & Benin & Mauritius & Andorra & Kyrgyzstan \\
\hline Bahrain & Papua New Guinea & Barbados & Botswana & Mozambique & Armenia & Latvia \\
\hline Bangladesh & Philippines & Belize & Burkina Faso & Namibia & Australia & Liechtenstein \\
\hline Bhutan & Qatar & Bolivia & Burundi & Niger & Austria & Lithuania \\
\hline Brunei & Saudi Arabia & Brazil & Cameroon & Nigeria & Azerbaijan & Luxembourg \\
\hline Burma & Singapore & Chile & Cape Verde & Rwanda & Belarus & Macedonia \\
\hline Cambodia & Solomon Islands & Colombia & Central African Rep. & Senegal & Belgium & Malta \\
\hline China & South Korea & Costa Rica & Chad & Sierra Leone & Bosnia & Moldova \\
\hline Egypt & Sri Lanka & Cuba & Comoros & Somalia & Bulgaria & Netherlands \\
\hline Fiji & Syria & Dominican Republic & Congo-Brazzaville & South Africa & Canada & New Zealand \\
\hline India & Taiwan & Ecuador & Djibouti & Sudan & Croatia & Norway \\
\hline Indonesia & Thailand & El Salvador & Equatorial Guinea & Swaziland & Cyprus & Poland \\
\hline Iran & Timor & Guatemala & Eritrea & Tanzania & Czech Rep (C-Slv.) & Portugal \\
\hline Iraq & Tunisia & Guyana & Ethiopia & Togo & Denmark & Romania \\
\hline Israel & Turkey & Haiti & Gabon & Uganda & Estonia & Russia \\
\hline Japan & UAE & Honduras & Gambia & Zaire & Finland & Slovakia \\
\hline Jordan & Vanuatu & Jamaica & Ghana & Zambia & France & Slovenia \\
\hline Kuwait & Vietnam & Mexico & Guinea & Zimbabwe & Georgia & Spain \\
\hline Laos & Western Sahara & Nicaragua & Guinea Bissau & & Germany & Sweden \\
\hline Lebanon & Yemen & Panama & Ivory Coast & & Greece & Switzerland \\
\hline Libya & & Paraguay & Kenya & & Hungary & Tajikistan \\
\hline Malaysia & & Peru & Lesotho & & Iceland & Turkmenistan \\
\hline Maldives & & Suriname & Liberia & & Ireland & $\mathrm{UK}$ \\
\hline Mongolia & & Trinidad \& Tobago & Madagascar & & Italy & Ukraine \\
\hline Morocco & & Uruguay & Malawi & & & United States \\
\hline Nepal & & Venezuela & Mali & & & Uzbekistan \\
\hline
\end{tabular}


Table 9- Effects of comprehensive women's rights gap as well as political, economic, and social rights gaps on female brain drain ratios controlling for multilateral resistance.

\begin{tabular}{|c|c|c|c|c|}
\hline $\begin{array}{l}\text { Estimation Method } \\
\text { Dependent Variable }\end{array}$ & $\begin{array}{l}\text { (I) } \\
\text { PPML } \\
\text { FBR }\end{array}$ & $\begin{array}{c}\text { (II) } \\
\text { PPML } \\
\text { FBR }\end{array}$ & $\begin{array}{c}\text { (III) } \\
\text { PPML } \\
\text { FBR }\end{array}$ & $\begin{array}{l}\text { (IV) } \\
\text { PPML } \\
\text { FBR }\end{array}$ \\
\hline $\begin{array}{l}\text { Women's Rights Gap } \\
\text { (Women's Rights Gap)2 }\end{array}$ & $\begin{array}{l}1.790^{* *} \\
(0.859) \\
-0.222^{*} \\
(0.109)\end{array}$ & & & \\
\hline $\begin{array}{l}\text { Women's economic Rights Gap } \\
\text { (Women's economic Rights Gap) }^{2}\end{array}$ & & $\begin{array}{l}3.182^{* *} \\
(1.539) \\
-0.364^{*} \\
(0.208)\end{array}$ & & \\
\hline $\begin{array}{l}\text { Women's Social Rights Gap } \\
\text { (Women's Social Rights Gap) }^{2}\end{array}$ & & & $\begin{array}{c}0.589 \\
(0.585) \\
-0.016 \\
(0.071)\end{array}$ & \\
\hline $\begin{array}{l}\text { Women's Political Rights Gap } \\
\text { (Women's Political Rights Gap) }{ }^{2}\end{array}$ & & & & $\begin{array}{l}2.444 \\
(2.133) \\
-0.674 \\
(0.453)\end{array}$ \\
\hline Common first language dummy & $\begin{array}{c}0.031 \\
(0.087)\end{array}$ & $\begin{array}{l}-0.037 \\
(0.084)\end{array}$ & $\begin{array}{c}0.015 \\
(0.085)\end{array}$ & $\begin{array}{c}0.019 \\
(0.085)\end{array}$ \\
\hline Colony dummy & $\begin{array}{l}-0.034 \\
(0.094)\end{array}$ & $\begin{array}{l}-0.000 \\
(0.090)\end{array}$ & $\begin{array}{l}-0.004 \\
(0.091)\end{array}$ & $\begin{array}{l}-0.006 \\
(0.091)\end{array}$ \\
\hline Log distance & $\begin{array}{l}-0.071^{*} \\
(0.043)\end{array}$ & $\begin{array}{l}-0.077^{*} \\
(0.041)\end{array}$ & $\begin{array}{l}-0.040 \\
(0.043)\end{array}$ & $\begin{array}{l}-0.080^{*} \\
(0.042)\end{array}$ \\
\hline Origin fixed effect & Yes & Yes & Yes & Yes \\
\hline Destination fixed effect & Yes & Yes & Yes & Yes \\
\hline Origin nest fixed effect & Yes & Yes & Yes & Yes \\
\hline Constant & $\begin{array}{l}-2.850^{* *} \\
(1.236)\end{array}$ & $\begin{array}{l}-1.667 \\
(1.302)\end{array}$ & $\begin{array}{l}-0.111 \\
(2.709)\end{array}$ & $\begin{array}{l}-4.008^{* *} \\
(1.651)\end{array}$ \\
\hline Observations & 3128 & 3354 & 3171 & 3340 \\
\hline $\mathrm{R}^{2}$ & 0.430 & 0.422 & 0.418 & 0.426 \\
\hline
\end{tabular}




\section{Appendix}

Table A1-Effects of women's rights gap on female brain drain ratio.

\begin{tabular}{|c|c|c|c|c|c|}
\hline & (I) & (II) & (III) & (IV) & (V) \\
\hline Estimation Method & OLS & OLS & Heckman & PPML & PPML \\
\hline Dependent Variable & $\log (\mathrm{FBR})$ & $\log (\mathrm{FBR}+1)$ & $\log (\mathrm{FBR})$ & FBR & $F B R>0$ \\
\hline \multirow[t]{2}{*}{ Women's Rights Gap } & $0.084^{* * * *}$ & $0.047^{* * * *}$ & $0.084^{* * * *}$ & $0.093^{* * *}$ & $0.082^{* * * *}$ \\
\hline & $(0.010)$ & $(0.005)$ & $(0.009)$ & $(0.014)$ & $(0.014)$ \\
\hline \multirow{2}{*}{ (Women's Rights Gap)2 } & $-0.007^{* * *}$ & $-0.004^{* * *}$ & $-0.007^{* * *}$ & $-0.009^{*}$ & -0.006 \\
\hline & $(0.002)$ & $(0.001)$ & $(0.002)$ & $(0.005)$ & $(0.004)$ \\
\hline \multirow[t]{2}{*}{ Origin-landlocked dummy } & $0.127^{* * *}$ & $0.060^{*}$ & $0.123^{* *}$ & 0.107 & 0.104 \\
\hline & $(0.046)$ & $(0.032)$ & $(0.049)$ & $(0.074)$ & $(0.070)$ \\
\hline \multirow[t]{2}{*}{ Origin small island dummy } & $0.222^{* *}$ & $0.158^{* *}$ & $0.217^{* *}$ & $0.350^{* *}$ & $0.335^{* *}$ \\
\hline & $(0.090)$ & $(0.062)$ & $(0.092)$ & $(0.147)$ & $(0.145)$ \\
\hline \multirow{2}{*}{ Origin-loggdp } & $-0.091^{* * *}$ & $-0.034^{* * * *}$ & $-0.091^{* * *}$ & $-0.102^{* * *}$ & $-0.127^{* * *}$ \\
\hline & $(0.016)$ & $(0.010)$ & $(0.015)$ & $(0.022)$ & $(0.022)$ \\
\hline \multirow[t]{2}{*}{ Origin-unemployment } & $-0.023^{* * * *}$ & $-0.013^{* * *}$ & $-0.023^{* * * *}$ & $-0.027^{* * *}$ & $-0.027^{* * *}$ \\
\hline & $(0.003)$ & $(0.002)$ & $(0.003)$ & $(0.005)$ & $(0.005)$ \\
\hline \multirow{2}{*}{ Destination-loggdp } & 0.023 & 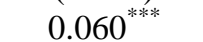 & 0.031 & 0.010 & $-0.061^{\text {*** }}$ \\
\hline & $(0.017)$ & $(0.011)$ & $(0.024)$ & $(0.030)$ & $(0.028)$ \\
\hline \multirow{2}{*}{ Destination - unemployment } & 0.004 & 0.001 & 0.004 & $-0.015^{* *}$ & $-0.015^{* *}$ \\
\hline & $(0.004)$ & $(0.003)$ & $(0.004)$ & $(0.006)$ & $(0.006)$ \\
\hline \multirow[t]{2}{*}{ Contiguity dummy } & 0.017 & -0.016 & 0.013 & -0.044 & -0.022 \\
\hline & $(0.081)$ & $(0.051)$ & $(0.084)$ & $(0.132)$ & $(0.124)$ \\
\hline \multirow[t]{2}{*}{ Common first language dummy } & $-0.191^{* * * *}$ & $-0.117^{* *}$ & $-0.187^{* *}$ & $-0.265^{* *}$ & $-0.258^{* *}$ \\
\hline & $(0.072)$ & $(0.052)$ & $(0.091)$ & $(0.108)$ & $(0.111)$ \\
\hline \multirow{2}{*}{ Common second language dummy } & $0.211^{* * * *}$ & $0.189^{* * * *}$ & $0.216^{* *}$ & $0.297^{* * *}$ & $0.198^{*}$ \\
\hline & $(0.070)$ & $(0.051)$ & $(0.089)$ & $(0.105)$ & $(0.107)$ \\
\hline \multirow[t]{2}{*}{ Colony dummy } & -0.037 & -0.009 & -0.034 & -0.002 & -0.014 \\
\hline & $(0.070)$ & $(0.044)$ & $(0.084)$ & $(0.129)$ & $(0.127)$ \\
\hline \multirow[t]{2}{*}{ Log distance } & 0.010 & -0.014 & 0.007 & 0.009 & 0.038 \\
\hline & $(0.019)$ & $(0.012)$ & $(0.020)$ & $(0.032)$ & $(0.031)$ \\
\hline \multirow[t]{2}{*}{ Origin government instability } & 0.201 & $-0.767^{* *}$ & 0.121 & -1.048 & -0.231 \\
\hline & $(0.446)$ & $(0.327)$ & $(0.494)$ & $(0.658)$ & $(0.610)$ \\
\hline \multirow{2}{*}{ Mills Test } & & & $1.660^{* * * *}$ & & \\
\hline & & & $(0.614)$ & & \\
\hline \multirow[t]{2}{*}{ Constant } & $0.914^{* * *}$ & $1.014^{* * *}$ & $0.855^{* * * *}$ & $1.872^{* * *}$ & $2.390^{* * * *}$ \\
\hline & (0.309) & $(0.201)$ & $(0.329)$ & $(0.484)$ & $(0.463)$ \\
\hline Observations & 2617 & 2970 & 3713 & 2970 & 2617 \\
\hline $\mathrm{F}$ & 25.625 & 23.618 & & & \\
\hline $\mathrm{R}^{2}$ & 0.125 & 0.093 & & 0.049 & 0.063 \\
\hline
\end{tabular}

Note: Standard errors in parentheses. ${ }^{*} p<0.10,{ }^{* *} p<0.05,{ }^{* * * *} p<.01$

Women's rights gap here is defined as the subtraction of the women's rights levels in origin from the women's rights levels in destination. 
Table A2 -Effects of women's rights gap on female brain drain ratio.

\begin{tabular}{|c|c|c|c|c|c|}
\hline & (I) & (II) & (III) & (IV) & (V) \\
\hline Estimation Method & OLS & OLS & Heckman & PPML & PPML \\
\hline Dependent Variable & $\log (\mathrm{FBR})$ & $\log (\mathrm{FBR}+1)$ & $\log (\mathrm{FBR})$ & FBR & FBR $>0$ \\
\hline \multirow[t]{2}{*}{ Women's Rights Gap } & $0.176^{* * *}$ & $0.091^{* * *}$ & $0.175^{* * *}$ & $0.136^{* * *}$ & $0.136^{* * *}$ \\
\hline & $(0.032)$ & $(0.019)$ & $(0.030)$ & $(0.047)$ & $(0.046)$ \\
\hline \multirow[t]{2}{*}{ (Women's Rights Gap)2 } & $-0.013^{* * *}$ & $-0.007^{* * *}$ & $-0.013^{* * *}$ & -0.008 & -0.008 \\
\hline & $(0.002)$ & $(0.001)$ & $(0.002)$ & $(0.005)$ & $(0.005)$ \\
\hline \multirow[t]{2}{*}{ Origin-landlocked dummy } & $0.120^{* * *}$ & $0.055^{*}$ & $0.114^{* *}$ & 0.104 & 0.102 \\
\hline & $(0.047)$ & $(0.033)$ & $(0.050)$ & $(0.074)$ & $(0.070)$ \\
\hline \multirow[t]{2}{*}{ Origin small island dummy } & $0.277^{* * *}$ & $0.193^{* * *}$ & $0.270^{* * *}$ & $0.417^{* * *}$ & $0.385^{* * *}$ \\
\hline & $(0.090)$ & $(0.062)$ & $(0.092)$ & $(0.148)$ & $(0.146)$ \\
\hline \multirow[t]{2}{*}{ Origin-loggdp } & $-0.127^{* * *}$ & $-0.057^{* * *}$ & $-0.127^{* * *}$ & $-0.141^{* * *}$ & $-0.158^{* * *}$ \\
\hline & $(0.015)$ & $(0.009)$ & $(0.014)$ & $(0.022)$ & $(0.021)$ \\
\hline \multirow[t]{2}{*}{ Origin-unemployment } & $-0.022^{* * *}$ & $-0.013^{* * *}$ & $-0.022^{* * *}$ & $-0.027^{* * *}$ & $-0.027^{* * *}$ \\
\hline & $(0.003)$ & $(0.002)$ & $(0.003)$ & $(0.005)$ & $(0.005)$ \\
\hline \multirow[t]{2}{*}{ Destination-loggdp } & $0.057^{* * *}$ & $0.079^{* * *}$ & $0.069^{* * *}$ & 0.047 & -0.026 \\
\hline & $(0.016)$ & $(0.010)$ & $(0.023)$ & $(0.029)$ & $(0.028)$ \\
\hline \multirow[t]{2}{*}{ Destination - unemployment } & $0.009^{* *}$ & 0.004 & $0.010^{* *}$ & -0.009 & $-0.010^{*}$ \\
\hline & $(0.004)$ & $(0.003)$ & $(0.004)$ & $(0.006)$ & $(0.006)$ \\
\hline \multirow[t]{2}{*}{ Contiguity dummy } & 0.046 & 0.002 & 0.040 & -0.009 & 0.005 \\
\hline & $(0.082)$ & $(0.052)$ & $(0.085)$ & $(0.132)$ & $(0.124)$ \\
\hline \multirow[t]{2}{*}{ Common first language dummy } & $-0.159^{* *}$ & $-0.101^{*}$ & $-0.154^{*}$ & $-0.242^{* *}$ & $-0.237^{* *}$ \\
\hline & $(0.073)$ & $(0.053)$ & $(0.092)$ & $(0.108)$ & $(0.111)$ \\
\hline \multirow[t]{2}{*}{ Common second language dummy } & $0.183^{* *}$ & $0.174^{* * *}$ & $0.190^{* *}$ & $0.273^{* * *}$ & $0.178^{*}$ \\
\hline & $(0.071)$ & $(0.052)$ & $(0.090)$ & $(0.105)$ & $(0.108)$ \\
\hline \multirow{2}{*}{ Colony dummy } & -0.042 & -0.013 & -0.038 & -0.011 & -0.022 \\
\hline & $(0.071)$ & $(0.045)$ & $(0.084)$ & $(0.130)$ & $(0.128)$ \\
\hline \multirow{2}{*}{ Log distance } & 0.011 & -0.014 & 0.007 & 0.013 & 0.043 \\
\hline & (0.019) & $(0.012)$ & $(0.020)$ & $(0.032)$ & $(0.031)$ \\
\hline \multirow[t]{2}{*}{ Origin government instability } & -0.014 & $-0.899^{* * *}$ & -0.125 & $-1.247^{*}$ & -0.393 \\
\hline & $(0.451)$ & $(0.329)$ & $(0.500)$ & $(0.667)$ & $(0.621)$ \\
\hline \multirow[t]{2}{*}{ Mills Test } & & & $2.226^{* * *}$ & & \\
\hline & & & $(0.622)$ & & \\
\hline \multirow[t]{2}{*}{ Constant } & $0.704^{* *}$ & $0.931^{\text {*** }}$ & $0.626^{*}$ & $1.664^{* * * *}$ & $2.148^{* * * *}$ \\
\hline & $(0.309)$ & $(0.199)$ & $(0.326)$ & $(0.464)$ & $(0.443)$ \\
\hline Observations & 2617 & 2970 & 3713 & 2970 & 2617 \\
\hline $\mathrm{F}$ & 22.162 & 17.716 & & & \\
\hline $\mathrm{R}^{2}$ & 0.108 & 0.078 & & 0.042 & 0.057 \\
\hline \multicolumn{6}{|c|}{$\begin{array}{l}\text { Women's rights variables here is computed based on adding women's social, economic and political rights in their } \\
\text { original form which is when they vary between } 0 \text { and } 3 \text {. Women's rights gap here is defined as ratio of women's } \\
\text { rights levels in destination to women's rights levels in origin. The only country with women's rights level of zero is } \\
\text { Afghanistan which was dropped to avoid unidentified values for women's rights gap variable. }\end{array}$} \\
\hline
\end{tabular}

